How to cite this article:

Adepoju, S. A., Oyefolahan, I. O., Abdullahi, M. B., \& Mohammed, A. A. (2020). Multicriteria decision making based approaches in website quality and usability evaluation: A systematic review. Journal of Information and Communication Technology, 19(3), 399-436. https://doi.org/10.32890/jict2020.19.3.5

\title{
MULTI-CRITERIA DECISION-MAKING BASED APPROACHES IN WEBSITE QUALITY AND USABILITY EVALUATION: A SYSTEMATIC REVIEW
}

\author{
${ }^{1}$ Solomon Adelowo Adepoju, ${ }^{2}$ Ishaq Oyebisi Oyefolahan, \\ ${ }^{1}$ Muhammed Bashir Abdullahi \& ${ }^{3}$ Adamu Alhaji Mohammed \\ ${ }^{1}$ Department of Computer Science, \\ Federal University of Technology Minna, Nigeria \\ ${ }^{2}$ Department of Information and Media Technology, \\ Federal University of Technology Minna, Nigeria \\ ${ }^{3}$ Department of Mathematics, \\ Federal University of Technology Minna, Nigeria
}

solo.adepoju,o.ishaq,el.bashir02, adamu.alhaj@futminna.edu.ng

\begin{abstract}
Websites are important in every organisation and tremendous effort is made to design websites that not only look and feel good, but are usable and of high quality. Nevertheless, one critical task is how to evaluate these websites to ensure that users are satisfied with its quality and usability. Although a variety of methods and approaches have been proposed, there is currently an increase in research efforts to model website quality and usability evaluation from the point of view of decision-makers which existing methods do not handle. Thus, this has led to the application of multi-criteria decision-making (MCDM) approaches in the evaluation of websites to handle complexity in decision-making. This paper, therefore, provides a review of the various MCDM methods that have been used in the usability and quality evaluation of websites. The search strategy which was adopted identified a total of 63 published articles in peer-
\end{abstract}


reviewed journals and international conferences between 2005 and 2017. From the research questions formulated for the study, the papers were classified into various MCDM approaches, website genre, number and list of criteria used over the years and the localization of websites based on country. Some of the findings showed that the Analytical Hierarchy Process approach integrated with fuzzy logic has been the most common method over the years. In addition, e-commerce websites make up the most common website genre. Besides, currently most active websites are from Turkey and five is the average number of criteria for the evaluation of website quality and usability.

Keywords: Decision making, website, usability, website evaluation, quality.

\section{INTRODUCTION}

Presently, a common platform for information searching by numerous users is through websites and hence, its evaluation has attracted the attention of various practitioners and researchers worldwide. In turn, this has resulted in a tremendous increase in website evaluation research (Blagec, Romagnoli, Boyce, \& Samwald, 2016; Roy \& Pattnaik, 2014; Simon, Carbonera, \& Custodio, 2017; Sun, Fong, Law, \& He, 2017). Website evaluation studies may be viewed from the perspective of quality, usability, accessibility, navigability or functionality, among others. Quality evaluation encompasses the totality of the evaluation as a whole, whereas usability evaluation involves the assessment of ease of use of a product in order to identify usability problems (Adepoju, Oyefolahan, Abdullahi, \& Mohammed, 2018a; Federici \& Borsci, 2017; Speicher, 2015). Functionality evaluation aims at evaluating the extent to which the functions embedded in a product are performing expected tasks (Diniz, Porto, \& Adachi, 2005).

One of the most important factors in website quality is website usability, and the evaluation is conducted in order to obtain measures of usability. The aim of the evaluation is targeted at improving usability or determining to what extent usability objectives have been achieved. Both website quality and usability evaluation encompass many criteria and have been evaluated using different quality models (Alptekin, Hall, \& Sevim, 2015; Jaroslaw, Paweł, \& Jarosław, 2016). Website usability can be carried out using a variety of methods. These are categorized as expert-based method, user and tool-based methods, soft computing based methods, analytical modelling based method and multiple-criteria decision-making (MCDM) based methods (Adepoju et al., 2018a; Fernandez, Insfran, \& Abrahão, 2011; Nagpal, Mehrotra, \& Bhatia, 2017). Among these methods, MCDM is gaining popularity and attracting researchers' attention of late. 
MCDM involves evaluating a real-world situation by using qualitative or quantitative criteria in certain and uncertain risky environments with the aim of finding a suitable course of action, choice, strategy or policy among several options (Zavadskas, Turskis, \& Simona, 2014). It is widely applicable in different areas like education, the military, engineering including supplier evaluation and selection (Asemi, Sapiyan, Asemi, \& Haji, 2013; Diaby, Campbell, \& Goeree, 2013; Ho, Xu, \& Dey, 2010; Mohsen, Madjid, Mimi, \& Majid, 2011; Safari \& Aghasi, 2014; Syke, Nina, Syke, \& Keune, 2013; Velasquez \& Hester, 2013). Currently, it is also widely applicable in website evaluation either from a usability or quality point of view (Adepoju et al., 2018b; Nagpal, Mehrotra, \& Bhatia, 2016; Nirmala \& Uthra, 2017; Perçin, 2017; Sagar \& Saha, 2017; Wardoyo \& Wahyuningrum, 2018).

The focus of this paper is on the review of the usage of MCDM approaches in website usability and quality evaluation. The purpose of this scholarly article is to identify trends in the literature on the application of MCDM approaches in the usability and quality evaluation of websites. Besides, this study looks at which genre of websites have been extensively evaluated using MCDM methods, the commonly used criteria, the number of criteria used in the studies including the location by country where the websites were used in previous studies. In addition to this, trends on the most widely used standalone and integrated MCDM methods are also investigated. The review considers papers that appeared in reputable journals and conference proceedings from 2005 to 2017. Conference papers are included because it is also an important avenue to disseminate the latest research results in the field of computer science.

Existing studies focused mainly on website quality using the MCDM approach and did not adopt a comprehensive literature review in the studies (Rekik, Kallel, Casillas, \& Alimi, 2016; Rekik, Kallell, \& Alimi, 2015). Others focused on a particular type of MCDM methodology (Asemi et al., 2013; Behzadian, Kazemzadeh, Albadvi, \& Aghdasi, 2010; Govindan \& Jepsen, 2015; Mardani, Zavadskas, \& Govindan, 2016). Hence, this paper aims to conduct a comprehensive review of MCDM approaches combining both website usability and quality evaluation based on available information. The remainder of this paper is organised as follows: The following section presents the overview of MCDM methods, followed by a description on the research methodology. Analysis of the review results is discussed after that and subsequently, the conclusion and suggestions for future work.

\section{OVERVIEW OF MULTI-CRITERIA DECISION-MAKING METHODS}

There have been efforts in the past to conduct a review on website quality and website usability. Some of these studies focused mainly on website usability 
evaluation trends (Das \& Patil, 2014; Fernandez et al., 2011; Gupta, 2015; Nawaz \& Clemmensen, 2013; Paz \& Pow-Sang, 2014). Recently, the use of MCDM or otherwise known as multiple-criteria decision analysis (MCDA) approach in measuring usability and quality of web interfaces is gaining prominence. MCDA is largely used when solving complex decision problems which involves multiple criteria by selecting the best alternative (Roy, Pattnaik, \& Mall, 2014; Stewart, 2012). According to Nagpal et al. (2017), MCDA entails studying the methods and procedures that incorporate multiple and conflicting criteria in the decision-making process. MCDM can be subdivided into: multi-attribute decision-making (MADM) and multi-objective decisionmaking (MODM). MADM methods involve solving problems with discrete decision spaces based on a predetermined or a restricted number of choices (Kubler, Robert, Derigent, Voisin, \& Le, 2016). It involves making selections among some courses of action in the presence of multiple usually conflicting finite attributes.

On the other hand, MODM involves the existence of decision variable values that are defined in a continuous or integer domain. This can either be an infinite or a large number of alternative choices, the best of which should satisfy the decision-makers' constraints and preference priorities. A common tool for measuring website performance is through the use of MCDM (Bali, Burmaoğlu, \& Kazançoğlu, 2010; Dominic, Jati, \& Kannabiran, 2010; Karabasevic \& Stanujkic, 2019). Various fields of studies have been found to solve decision-making problems using MCDM and these include engineering and computer science applications (Rekik, Kallel, \& Casillas, 2016; Sunny et al., 2017), agriculture (Grigera et al., 2018), banking (Wanke, Azad, Barros, \& Hadi-vencheh, 2015), tourism (Qi, Law, \& Buhalis, 2017a; Soleymaninejad, Shadifar, \& Karimi, 2016), and aviation (Percin \& Aldalou, 2018).

As described earlier MCDM involves subjective evaluation of a finite number of alternatives under a finite number of criteria by a decision-maker or group expert through the design of computational and mathematical tools (Kubler et al., 2016; Si, You, Liu, \& Zhang, 2018). It simply involves making a decision by selecting the best alternative in the presence of multiple criteria. There are different types of MCDM methods. These include: Analytical Hierarchy Processing (AHP), Technique for Order Preference by Similarity to Ideal Solution (TOPSIS), Analytical Network Processing (ANP), Preference Ranking Organization METHod for Enrichment Evaluations (PROMETHEE), Decision-Making Trial and Evaluation Laboratory (DEMATEL), ELimination Et Choix Traduisant la Réalité or Elimination and Choice Translating Reality (ELECTRE), Multi-Attribute Utility Theory (MAUT) and Vlse Kriterijumska Optimizacija I Kompromisno Resenje (VIKOR). Some of these methods are described briefly as follows. 
AHP was developed by Saaty and it involves modelling decisionmaking problems in hierarchies of goals, criteria, sub-criteria and alternatives. Pairwise comparisons of the criteria are performed to measure relative importance at each hierarchical level and the alternatives are evaluated from the lowest to the highest level of the hierarchy in making decisions (Roy, Jagannath Kajal Chatterjee, Bandyopadhyay, \& Kar, 2018; Samanlioglu \& Ayag, 2018). ANP is a generic form of AHP which gives room for more relationship, interdependence, complexity and feedback among the hierarchy elements. It enables functional interdependency among decision-makers to be defined among the deciding factors which belong to different levels and the same level of a hierarchy (Rekik, Kallel, \& Alimi, 2016; Tavana, Yazdani, \& Di-Caprio, 2017). Fuzzy AHP is another variant of AHP proposed earlier by Saaty. It was developed to handle subjectivity and uncertainty observed in complex decision problems. It is integrated with fuzzy set theory.

TOPSIS is an MCDM technique that is used in identifying solutions from a finite set of alternatives based on their distances from positive ideal solutions (PIS) and negative ideal solutions (NIS). The alternatives to be chosen have the shortest distance from the PIS and the farthest distance from the NIS (Alptekin et al., 2015; Ceballos, Teresa, \& David, 2016). PROMETHEE belongs to the family of outranking methods in MCMD and was first introduced by Brans in 1982 for partial and complete ranking of alternatives. As an outranking method, a finite set of alternative actions has to be ranked and selected among many conflicting criteria. With the advancement of this method, the iterations of this method have improved (Çelik \& Cansu, 2017; Zavadskas et al., 2014).

ELECTRE was developed in 1965 and is an outranking method that is used for choosing the best action from a given set of actions. It consists of aggregation and exploitation phases. The aggregation phase involves the construction of pairwise comparisons with the use of concordance and non-discordance concepts. The second phase of exploitation is aimed at constructing and presenting expected results for a given problem. In addition to the decision matrix, preference information in the form of weights, thresholds, and other parameters are vital in ELECTRE (Govindan \& Jepsen, 2015; Kaya \& Kahraman, 2013). DEMATEL is a structural modelling approach used in analysing the cause and effect relationships among system components. It helps managers to know how to assess direct and indirect relations and to construct a map to reflect relative relationships within them. This can be used to investigate further to solve complicated problems (Si et al., 2018; Zhou, Hu, Deng, Chan, \& Ishizaka, 2018).

The key aim of MCDM methods is to assist decision-makers to deal with complex problems which may take the form of evaluation, selection and prioritisation through the imposition of a disciplined methodology. Website usability and website quality fall can be solved by using MCDM approach as they fall under the selection or evaluation process (Kubler et al., 2016). 
Rekik et al. (2016) explored known MCDM techniques to assess website information in specific domains or identify current developments in online literature. In general, various steps are involved to solve an MCDM problem as proposed by Dodgson, Spackman, Pearman and Phillips (2009) which is shown in Figure 1.

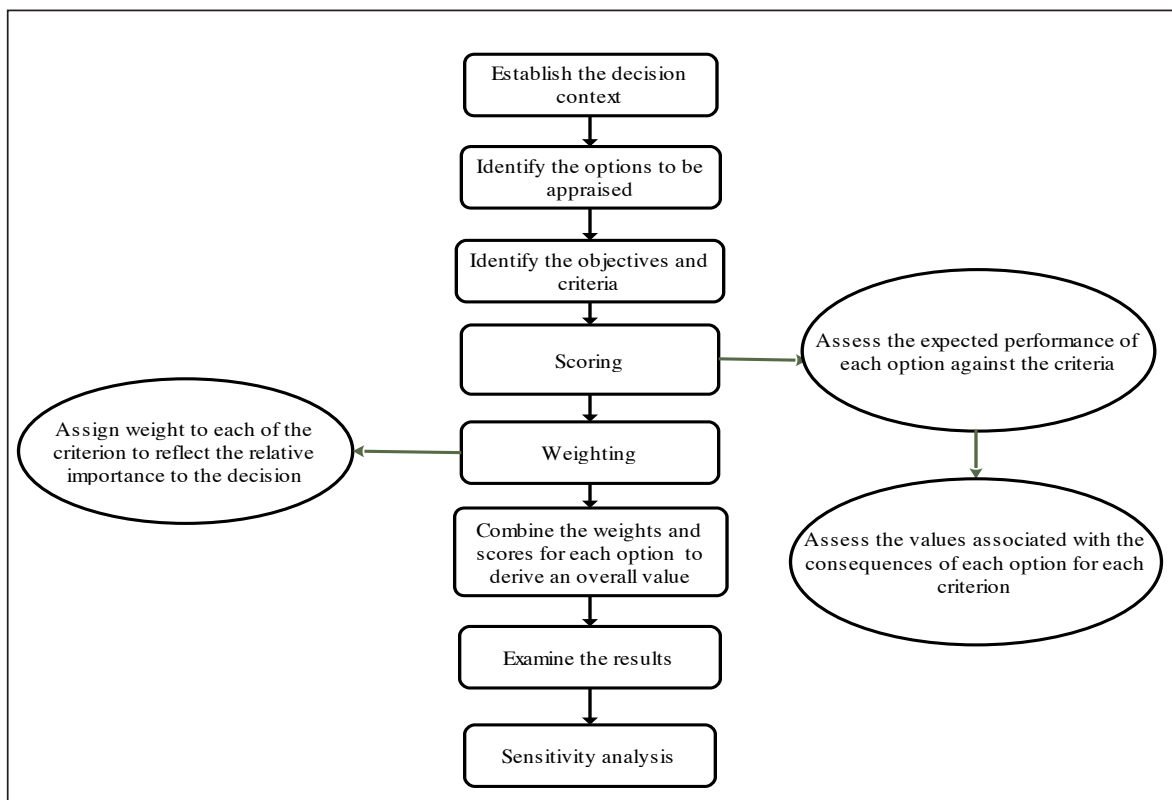

Figure 1. Steps of MCDA (Dodgson et al., 2009)

Past reviews on applications of some MCDM methods in different domains have been carried out by different researchers. Examples of such studies include Zare et al. (2016) who focused on MCDA approaches in e-learning; Das and Patil (2014) who described general usability evaluation methods and Behzadian et al. (2010) who reviewed Preference Ranking Organization Method for Enrichment Evaluation (PROMETHEE) which is a MCDA method. Besides, reviews on MCDA applications was conducted by Mardani et al. (2015) and Ugras et al. (2016) and studies on ELimination and Choice Expressing Reality (ELECTRE) which is also one of the MCDA approaches was conducted by Govindan and Jepsen (2015).

MCDA reviews with a focus on website quality were performed by Rekik et al. (2015) and Rekik et al. (2016). In addition to this, Nagpal et al. (2017) conducted a review of the current trends in usability evaluation methods. There were also studies on research trends in website usability (Ugras et al., 
2016), systematic evaluation of the web (Fernandez et al., 2011) and a review of website usability in the Asian continent (Nawaz \& Clemmensen, 2013). Findings from previous studies showed the popular usage of the MCDM approach in different domains which enhanced the need to explore its trend in website evaluation. To the best of our knowledge, there is no study conducted to review MCDM based approaches with a focus on website usability and quality evaluation, using a systematic review approach. Also, existing reviews failed to give a detailed classification as compared to this paper which intends to fill the gap.

\section{RESEARCH METHODOLOGY}

This review was undertaken in order to realize the trend in the usage of MCDM approaches in website quality and usability evaluation using the systematic literature review (SLR) approach proposed by Kitchenham and Charters (2007) which has been used recently in several studies (Quiñones \& Rusu, 2017; Rekik, Kallel, Casillas, \& Alimi, 2018). The SLR process is made up of three stages namely, planning the review, conducting the review and reporting the review. These phases are shown in Figure 2.

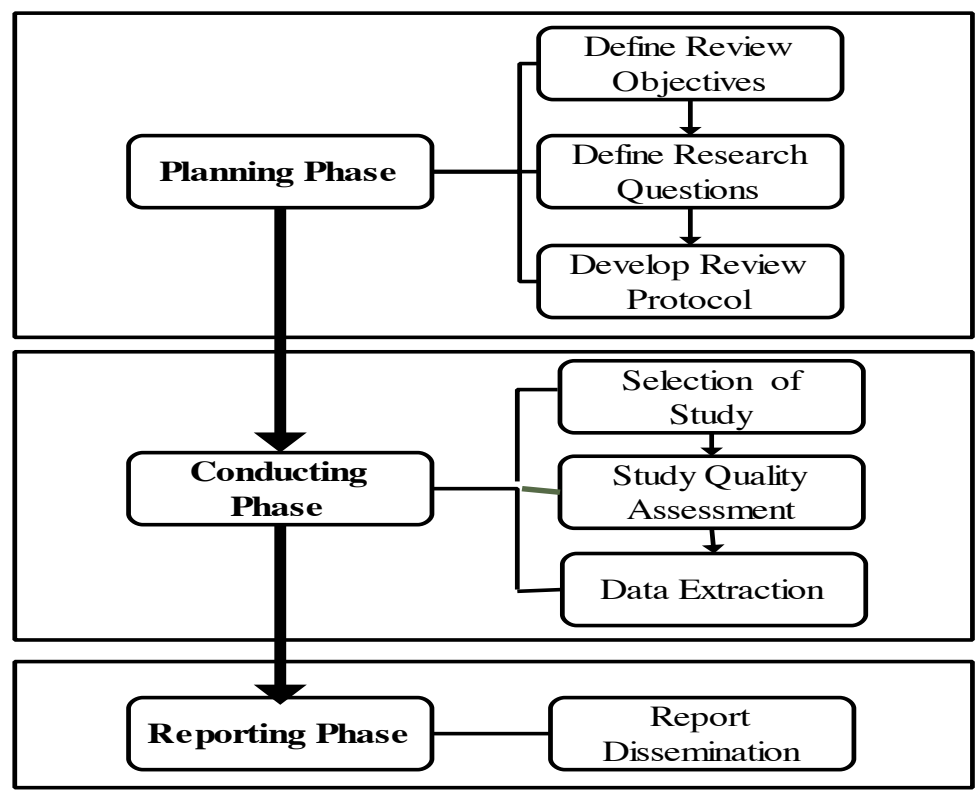

Figure 2. Phases in systematic literature review (Kitchenham \& Charters, 2007) 
The planning stage involves identifying review needs, starting the review, specifying research questions, and developing and evaluating review protocol which involves search strategies and terms and study selection criteria. Conducting the review stage deals with the selection of primary studies, data extraction, data monitoring and data synthesis. Reporting the review involves dissemination of the review report. The details of these are described in the next section.

To guide in the search and presentation of the results, this article attempts to answer the following research questions:

RQ1 : What is the number of studies undertaken in the evaluation of website quality and usability using the MCDM approach over the years?

RQ2 : What is the genre of website(s) which most commonly apply MCDM methods?

RQ3 : What are the MCDM approaches used in website usability and quality evaluation?

RQ4 : What is the number of criteria often used in MCDM methods?

RQ5 : What is the location of the websites by country used in the studies?

The search strategies used for the study involved searching and collecting articles through the use of several digital library databases including IEEEXplore, Springer Link, Elsevier, Science Direct, Inderscience, and Taylor and Francis. These include major journals and conferences in operation research, computer science and allied disciplines. Also, Database hosts like Scopus and general online search engines such as Google Scholar was also used to search for relevant works. Cross-references that were relevant in reviewed articles were searched to collect papers from standalone journals and publishers whose library databases could not be accessed. Other sources include literature from peer-reviewed academic journals and reputable conferences. Publications from books, dissertations and other unreliable sources were excluded from the study. Only papers published from 2005 to 2017 were included in the study. This is because the authors could not retrieve any articles on MCDM approach in website usability and quality evaluation before 2005 .

The search terms used were "website usability" OR "web site usability" OR "web site quality" OR "website quality" AND "multi-criteria decision analysis" OR "multi-criteria decision-making." Articles were analysed based on various MCDM approaches, the number of article publications by year, the number of criteria used, the genre of websites evaluated and country of website affiliation. The search string was applied to the title, abstract and keywords of each article for all the sources. The same search string was applied to all other sources where the articles were manually sourced from in order to ensure conformity. Initially, a total of 902 articles were retrieved from the search. However, after a thorough review and the elimination of duplicate 
or repeated articles including using search criteria (based on inclusion and exclusion criteria as stated), finally 63 articles comprising 48 journal articles and 15 conference papers were used for the review.

\section{RELATED WORK ON MCDM APPROACHES IN WEBSITE USABILITY AND QUALITY EVALUATION}

As mentioned, MCDM methods are frequently used in solving problems which have multiple, inconsistent, and disproportionate criteria and/or objectives in real-world scenarios (Kubler et al., 2016). This simply involves making a decision by selecting the best alternative in the presence of multiple criteria. The key aim of MCDM methods is assisting decision-makers to deal with complex problems which may take the form of evaluation, selection and prioritisation through the imposition of a disciplined methodology. Website usability and website quality fall can be solved by using MCDM approach as they fall under the selection or evaluation process (Kubler et al., 2016). Rekik et al. (2016) explored known MCDM techniques to assess website information in specific domains or identify current developments in online literature. This paper identifies the MCDM methodology and provides a comparison of existing research. The breakdown of the previous studies is shown in Tables 1 and 2 .

Table 1 shows the studies which focus on the use of MCDM approaches in website usability evaluation and Table 2 presents the MCDM approaches in website quality evaluation. Six studies have been found to apply MCDM approaches as shown in Table 1 and the types of the websites are basically education, e-government, finance, ecological parks, e-commerce including hotels. Altogether there is a total of 12 studies. In contrast to Table 1, MCDM approaches in Table 2 have been widely applied in almost all types of websites including hospitals, airlines, political parties, e-shopping, e-learning and banking. Thus, more focus has been on applying MCDM approaches to website quality compared to website usability.

Table 1

Studies on website usability evaluation using MCDM approach

\begin{tabular}{lll}
\hline Website Type & Author(s) & Criteria used \\
\hline Education & Nagpal et al. (2015a), Nagpal, & Ease of use, response time, \\
& Mehrotra and Bhatia (2016b), & navigable, informative. \\
& Nagpal et al. (2015b) & \\
\hline
\end{tabular}

(continued) 


\begin{tabular}{|c|c|c|}
\hline Website Type & Author(s) & Criteria used \\
\hline \multirow{5}{*}{ E-government } & Roy, Kumar and Rajib (2016) & $\begin{array}{l}\text { Attractiveness, controllability, } \\
\text { efficiency, helpfulness, learnability }\end{array}$ \\
\hline & Delice and Gungor (2009) & $\begin{array}{l}\text { Design consideration, operation of } \\
\text { website, website user accordance }\end{array}$ \\
\hline & Lamichhane and Meesad (2011) & $\begin{array}{l}\text { Adequacy of information, update } \\
\text { and interaction, appearance and } \\
\text { outline, navigation }\end{array}$ \\
\hline & Guimei and Taowei (2012) & $\begin{array}{l}\text { Service, technology, system } \\
\text { structure, culture }\end{array}$ \\
\hline & Byun and Finnie (2011) & $\begin{array}{l}\text { Contents page, navigation, ease of } \\
\text { learning, interaction, functionality }\end{array}$ \\
\hline Finance & Presley and Fellows (2013) & $\begin{array}{l}\text { Content, ease of use, promotion, } \\
\text { made for the medium, emotion }\end{array}$ \\
\hline Ecological park & Zhang, Zhao, Feng, and Li (2015) & $\begin{array}{l}\text { Topicality, functionality, } \\
\text { information elements }\end{array}$ \\
\hline E-commerce & Masudin and Saputro (2016) & $\begin{array}{l}\text { Trustworthiness, shopping } \\
\text { support, information access } \\
\text { efficiency, ease of apprehension, } \\
\text { hedonic quality }\end{array}$ \\
\hline Hotel & Qi, Law and Buhalis (2017a) & Effectiveness, safety, flexibility \\
\hline
\end{tabular}

Table 2

Studies on website quality evaluation using MCDM approach

\begin{tabular}{lll}
\hline Website Type & \multicolumn{1}{c}{ Author(s) } & \multicolumn{1}{c}{ Criteria Used } \\
\hline E-banking & Kaya and Kahraman (2011) & $\begin{array}{l}\text { Product quality, reliability, } \\
\text { competence, responsiveness, } \\
\text { access, information content, } \\
\end{array}$ \\
& Ecer (2014) & ease of use, security \\
& & Information quality, service \\
& quality, system quality \\
Education & Lin (2010) & System quality, information \\
& & quality, service, attractiveness \\
\hline
\end{tabular}




\begin{tabular}{|c|c|c|}
\hline Website Type & Author(s) & Criteria Used \\
\hline \multirow{6}{*}{ Travel } & $\begin{array}{l}\text { Kostoglou, Papathanasiou and } \\
\text { Moschidis (2014) }\end{array}$ & $\begin{array}{l}\text { Coverage and content, web } \\
\text { services, technical and aesthetic } \\
\text { completeness, presentation of } \\
\text { research objectives, objectivity }\end{array}$ \\
\hline & Dominic and Jati (2010) & $\begin{array}{l}\text { Load time, response time, page } \\
\text { rank, frequency of update, } \\
\text { traffic, design optimization, size, } \\
\text { number of items, accessibility } \\
\text { error, markup validation, and } \\
\text { broken link }\end{array}$ \\
\hline & Lee, Chiang and Chen (2012) & $\begin{array}{l}\text { Efficiency, privacy, reliability, } \\
\text { responsiveness, personalization }\end{array}$ \\
\hline & Kabir and Hasin (2012) & $\begin{array}{l}\text { Efficiency, privacy, reliability, } \\
\text { responsiveness, personalization }\end{array}$ \\
\hline & $\begin{array}{l}\text { Soleymaninejad, Shadifar and } \\
\text { Karimi (2016) }\end{array}$ & $\begin{array}{l}\text { Visibility and findability, visual } \\
\text { design and content, functionality } \\
\text { and accessibility, technology, } \\
\text { customer engagement, online } \\
\text { bookability }\end{array}$ \\
\hline & $\mathrm{Hu}(2009)$ & $\begin{array}{l}\text { Efficiency, fulfilment, system } \\
\text { availability, security/privacy, } \\
\text { responsiveness, compensation, } \\
\text { contact, benefit, customization/ } \\
\text { personalization, tangibility, } \\
\text { assurance/trust, continuous } \\
\text { improvement }\end{array}$ \\
\hline \multirow{5}{*}{ Airline } & Younghwa and Kenneth (2006) & $\begin{array}{l}\text { Information quality, system } \\
\text { quality, service quality, vendor- } \\
\text { specific }\end{array}$ \\
\hline & Law (2007) & Content, layout, security, price \\
\hline & $\begin{array}{l}\text { Bali, Burmaoğlu and } \\
\text { Kazançoğlu (2010) }\end{array}$ & $\begin{array}{l}\text { Visual design, navigation, } \\
\text { content, security and } \\
\text { responsiveness }\end{array}$ \\
\hline & Khan and Dominic (2013) & $\begin{array}{l}\text { Load time, response time, page } \\
\text { rank, frequency of update, } \\
\text { traffic, design, size, number } \\
\text { of items, accessibility errors, } \\
\text { markup validation, broken link }\end{array}$ \\
\hline & Çelik and Cansu (2017) & $\begin{array}{l}\text { Efficiency, system availability, } \\
\text { fulfilment, privacy }\end{array}$ \\
\hline
\end{tabular}




\begin{tabular}{|c|c|c|}
\hline Website Type & Author(s) & Criteria Used \\
\hline \multirow[t]{2}{*}{ Hospital } & $\begin{array}{l}\text { Bilsel, Büyüközkan, and Ruan } \\
\text { (2006) }\end{array}$ & $\begin{array}{l}\text { Tangibility, reliability, } \\
\text { responsiveness, confidence, } \\
\text { empathy, quality of information, } \\
\text { integration of common issues }\end{array}$ \\
\hline & $\begin{array}{l}\text { Mirbargkar and Zadmehr } \\
\text { (2015) }\end{array}$ & $\begin{array}{l}\text { Tangibility, reliability, } \\
\text { responsiveness, confidence, } \\
\text { empathy, quality of information, } \\
\text { assurance, empathy }\end{array}$ \\
\hline Political party & $\begin{array}{l}\text { Aytuna, Karsak and Albayrak } \\
\text { (2012) }\end{array}$ & $\begin{array}{l}\text { Functionality, efficiency, } \\
\text { usability, reliability, } \\
\text { interactivity }\end{array}$ \\
\hline \multirow[t]{3}{*}{ Tourism } & Tsai, Chou and Lai (2010) & $\begin{array}{l}\text { Navigability, speed, links, } \\
\text { relevancy, richness, currency, } \\
\text { attractiveness }\end{array}$ \\
\hline & $\begin{array}{l}\text { Lian, Yu, Wang and Hou } \\
\text { (2016) }\end{array}$ & $\begin{array}{l}\text { Visual appeal, information } \\
\text { accuracy and abundance, } \\
\text { navigation, convenience and } \\
\text { website interaction }\end{array}$ \\
\hline & Stanujkic (2014) & $\begin{array}{l}\text { Design, authority, accuracy, } \\
\text { adaptability, currency, } \\
\text { navigation }\end{array}$ \\
\hline $\begin{array}{l}\text { Professional } \\
\text { accounting } \\
\text { firm }\end{array}$ & Chou and Cheng (2012) & $\begin{array}{l}\text { Accessibility, navigability, } \\
\text { usability, privacy, relevance, } \\
\text { understandability, richness, } \\
\text { currency, responsiveness, } \\
\text { reliability, assurance, empathy }\end{array}$ \\
\hline \multirow[t]{3}{*}{ E-government } & $\begin{array}{l}\text { Burmaoglu and Kazancoglu } \\
\text { (2012) }\end{array}$ & $\begin{array}{l}\text { E-democracy, e-service, website } \\
\text { design }\end{array}$ \\
\hline & $\begin{array}{l}\text { Markaki, Charilas and } \\
\text { Askounis (2010) }\end{array}$ & $\begin{array}{l}\text { Usability, content, site quality, } \\
\text { e-service. e-democracy feature }\end{array}$ \\
\hline & $\begin{array}{l}\text { Dominic, Jati and Sellappan } \\
\text { (2011) }\end{array}$ & $\begin{array}{l}\text { Load time, response time, page } \\
\text { rank, frequency of update, } \\
\text { traffic, design optimization, } \\
\text { size, number of items, } \\
\text { accessibility error, markup } \\
\text { validation, and broken link }\end{array}$ \\
\hline
\end{tabular}




\begin{tabular}{|c|c|c|}
\hline Website Type & Author(s) & Criteria Used \\
\hline \multirow[t]{10}{*}{ E-commerce } & $\begin{array}{l}\text { Yi-wen, Kwon and Kang } \\
\text { (2007) }\end{array}$ & $\begin{array}{l}\text { Design, information, technique, } \\
\text { service }\end{array}$ \\
\hline & Aydin and Kahraman (2011) & $\begin{array}{l}\text { Ease of use, product, security, } \\
\text { customer relationship, } \\
\text { fulfilment }\end{array}$ \\
\hline & Vatansever and Akgu (2014) & $\begin{array}{l}\text { Information quality, system } \\
\text { quality, service quality, vendor- } \\
\text { specific }\end{array}$ \\
\hline & $\begin{array}{l}\text { Alptekin, Hall and Sevim } \\
\text { (2015) }\end{array}$ & $\begin{array}{l}\text { Information quality, system } \\
\text { quality, service quality, vendor- } \\
\text { specific }\end{array}$ \\
\hline & Kaya (2010) & $\begin{array}{l}\text { Information quality, system } \\
\text { quality, service quality, vendor } \\
\text { quality }\end{array}$ \\
\hline & $\begin{array}{l}\text { Yu, Guo, Guo, and Huang } \\
\text { (2011) }\end{array}$ & $\begin{array}{l}\text { Price, abundance, appearance, } \\
\text { ease of use, security, } \\
\text { intelligence, confidence, trust, } \\
\text { speed }\end{array}$ \\
\hline & Agirgun (2012) & $\begin{array}{l}\text { Ease of use, product, security, } \\
\text { customer relationship, } \\
\text { fulfilment }\end{array}$ \\
\hline & $\begin{array}{l}\text { Zaim, Ramdani and Haddi } \\
\text { (2016) }\end{array}$ & $\begin{array}{l}\text { Security and privacy, content } \\
\text { (clarity, online services) design } \\
\text { (usefulness, graphical interface) }\end{array}$ \\
\hline & Aydin and Kahraman (2012) & $\begin{array}{l}\text { Ease of use, product, security, } \\
\text { customer relationship }\end{array}$ \\
\hline & Kong and Liu (2005) & $\begin{array}{l}\text { Trust, system quality, content } \\
\text { quality, online service, use }\end{array}$ \\
\hline E-procurement & Kabak and Burmaoğlu (2013) & $\begin{array}{l}\text { Navigability, speed, } \\
\text { standardization, links, accuracy, } \\
\text { richness, attractiveness, } \\
\text { reliability, personalization, } \\
\text { responsiveness. }\end{array}$ \\
\hline \multirow[t]{2}{*}{ Hotel } & $\begin{array}{l}\text { Akincilar and Dagdeviren, } \\
\text { (2014) }\end{array}$ & $\begin{array}{l}\text { Customer-oriented, technology- } \\
\text { oriented, marketing oriented, } \\
\text { security-oriented }\end{array}$ \\
\hline & $\begin{array}{l}\text { Shahin, Pool and Poormostafa } \\
\text { (2014) }\end{array}$ & $\begin{array}{l}\text { Usability, service interaction, } \\
\text { information quality }\end{array}$ \\
\hline
\end{tabular}




\begin{tabular}{|c|c|c|}
\hline Website Type & Author(s) & Criteria Used \\
\hline \multirow[t]{2}{*}{ E learning } & $\begin{array}{l}\text { Büyüközkan, Arsenyan and } \\
\text { Ertek (2010) }\end{array}$ & $\begin{array}{l}\text { Right and understandable } \\
\text { content, complete content, } \\
\text { personalization, security, } \\
\text { navigation, interactivity, user } \\
\text { interface }\end{array}$ \\
\hline & Garg and Jain (2017) & $\begin{array}{l}\text { Functionality, maintainability, } \\
\text { portability, reliability, usability, } \\
\text { efficiency, ease of learning } \\
\text { community, personalization, } \\
\text { system content, general factors }\end{array}$ \\
\hline \multirow[t]{3}{*}{ E-shopping } & $\begin{array}{l}\text { Dey, Jana, Gourisaria, } \\
\text { Mohanty and Chatterjee, } \\
(2015)\end{array}$ & $\begin{array}{l}\text { Website design and usability, } \\
\text { product, security, service } \\
\text { quality, fulfilment }\end{array}$ \\
\hline & Sun and Lin (2009) & $\begin{array}{l}\text { Efficiency, practical, } \\
\text { ease of use, time-saving, } \\
\text { communication, confident, } \\
\text { security, trust, familiarity, } \\
\text { past experience, proficiency, } \\
\text { knowledgeable }\end{array}$ \\
\hline & Nirmala and Uthra (2017) & $\begin{array}{l}\text { Service, information, website, } \\
\text { system, vendor-specific }\end{array}$ \\
\hline
\end{tabular}

\section{MCDM Approach in Educational Website Usability and Quality Evaluation}

One of the early users of websites comprised academic institutions (colleges, universities, polytechnics, institutes). In considering the role websites play in academic institutions, some studies have used various MCDM approaches in evaluating both the quality and usability of academic websites. These studies are grouped under university, college or portal website evaluation, e-learning website evaluation and library website evaluation. Some of these studies are discussed as follows.

Nagpal, Mehrotra, Bhatia, and Sharma (2015b) used fuzzy AHP to rank four Indian educational institutes on usability. The study criteria were based on response time (RT), ease of use (EOU), ease of navigation (EON) and informative (INF). Further studies by the same authors combined the use of fuzzy AHP and fuzzy TOPSIS to rank four university websites. An integration of fuzzy AHP and entropy approach was used to determine the usability of six academic websites based on the same four criteria as previously used (Nagpal 
et al., 2016). It was reported in the results that response time contributed the most to academic website usability by using the entropy approach, while easeof-use contributed the most to academic website usability by using Fuzzy AHP. Büyüközkan et al. (2010) evaluated the e-learning website using fuzzy axiomatic and fuzzy TOPSIS. The method incorporated requirements which enabled a reduction in the size of a problem(s).

Dominic and Jati (2010) in their study proposed a quality evaluation model based on fuzzy AHP for five university websites in Malaysia. Furthermore, quality evaluation of five university websites in Malaysia using 11 criteria obtained from automated tools was also conducted by Dominic et al. (2013). The outcome of the research indicated that the selected Malaysian universities were not paying adequate attention to performance and quality criteria. The ranking of Greek universities based on quality by using AHP was also conducted by Kostoglou, Papathanasiou, and Moschidis (2014). The study was based on five criteria and employed the simos method. Results obtained showed that coverage/content and web services received the highest weighting while objectivity and presentation of research obtained the least weighting.

Garg and Jain (2017) evaluated e-learning websites using fuzzy AHP for weight selection in their study. A combination of COPRAS (COmplex Proportional ASssessment), VIKOR and WDBA (Weighted Distance Based Approximation) were used for the ranking. The results showed that the developed model used in the study was effective and efficient in its assessment. Jain, Garg, and Bansal (2015) carried out an assessment of the quality of e-learning websites using TOPSIS. A total of 21 e-learning websites based on seven criteria were used for the study. Usability analysis on a university website was also evaluated by combining AHP and Heuristic evaluation method based on the severity of usability problems detected from the website (Delice \& Gungor, 2009). Lin (2010) also evaluated course websites using FAHP based on four criteria grouped into 16 sub-criteria among different independent groups.

\section{MCDM Approach in E-commerce Website Usability and Quality Evaluation}

E-commerce websites are also very important considering its impact on the economy of any given country. Masudin and Saputro (2016) applied fuzzy AHP and fuzzy TOPSIS to conduct usability evaluation on two e-commerce B2C websites. Five criteria of trustworthiness, shopping support, information access efficiency, ease of comprehension and hedonic quality were applied. It was further subdivided into 15 sub-criteria. The results of fuzzy AHP showed that security and privacy were the most important criteria, followed 
by trust, loading time, easy transaction, and e-payment support, respectively. The quality of three e-commerce websites in Turkey was examined by using fuzzy AHP and fuzzy VIKOR as stated in a study by Aydin and Kahraman (2012). Five main criteria and 20 sub-criteria were used in the study and the methodology proposed were reported to provide the advantage of having the ability to use both positive and negative fuzzy numbers to evaluate hierarchy.

Fuzzy AHP was also applied to determine success factors in e-commerce websites in a study conducted by Kong and Liu (2005). It involved five criteria of trust, system quality, content quality, online service and use which were further subdivided into 17 sub-criteria. The most important criteria were found to be trust and online service, with security and tracking order status being the most critical factors under each of these two criteria. Younghwa and Kenneth (2006) in their study was focused on selecting the most preferred website based on website quality factors and their relative importance. The association between website preference and financial performance was well considered. DeLone and McLean's Information System (IS) success model was extended through the application of AHP on some e-business companies in the study.

The objective of the study by Rekik et al. (2016) was to secure the best criteria for the evaluation of the quality of e-commerce websites using fuzzy ANP based on eight criteria. The study concluded based on the results that customer satisfaction and transaction security are the two most important criteria for a successful e-commerce website. Yi-wen et al. (2007) proposed the use of fuzzy AHP approach to evaluate e-commerce websites using four criteria which were further grouped into different sub-criteria. The results obtained when compared with the AHP method were found to be consistent. In another study, a model for web interface evaluation of e-procurement website was developed by Kabak and Burmaoğlu (2013). Combinations of DEMATEL, ANP and fuzzy set theory were used to develop the model. A total of 10 criteria were used and the results obtained from the study showed that standardisation, links, reliability and navigability are the most important criteria when evaluating e-procurement websites.

Similarly, shopping websites were evaluated using MCDM by Sun and Lin (2009). Fuzzy TOPSIS method was used to evaluate the competitive advantage of four shopping websites based on 12 criteria. It was discovered based on the results that security and trust are the most important factors needed to improve the competitive advantage of these websites. Vatansever and Akgu (2014) applied fuzzy AHP to measure the service quality of private e-shopping websites in Turkey. Four criteria and 22 sub-criteria were used. From the analysis of results, vendor-specific quality was the most significant factor which affected the quality of the website. This was followed by service quality, system quality and information quality, respectively. An exploratory study to determine usability factors in e-commerce websites was also conducted by Pearson and Pearson (2008). Five criteria involving: navigation, 
customization and personalisation, download speed, accessibility and ease of use were used. It was discovered in the findings that, ease-of-use and navigation were two critical components in determining e-commerce website usability.

$\mathrm{Yu}$ et al. (2011) integrated AHP and fuzzy TOPSIS to rank five e-commerce websites based on nine criteria. The criteria were speed, confidence, appearance, price, abundance, intelligence, security, ease-of-use and trust. Dey et al. (2015) developed a hybrid evaluation model that combined the use of AHP and fuzzy TOPSIS. Six major e-shopping websites of India were considered as alternatives and six important criteria factors which influenced online shopping the most were taken into consideration. Results obtained from the study indicated that price and quality of product, purchase security, account privacy statement and customer support were five top most influential criteria in online purchasing in the Indian market. A fuzzy MCDM approach for evaluating $\mathrm{B} 2 \mathrm{C}$ e-commerce websites was also developed by Liang et al. (2017). It was developed using single-valued trapezoidal neutrosophic decision-making trial and evaluation laboratory (SVTN-DEMATEL). Four criteria of efficiency, fulfilment, system availability and privacy were used to evaluate six e-commerce websites in China. The outcome of the research showed that impact factors affecting e-commerce services were affected by different priority levels and interrelationships.

\section{MCDM Approach in E-government Website Usability and Quality Evaluation}

MCDM approaches have also been applied in e-government website evaluation. Byun and Finnie (2011) in their study proposed AHP method in order to assess the usability of e-government websites and ranking of Australian state government portals. Six main usability criteria and 59 sub-criteria were used. Markaki et al. (2010) applied fuzzy AHP to evaluate the quality of e-government websites using five criteria subdivided into $17 \mathrm{sub}$-criteria. The results obtained indicated that the e-service axis was the most important factor which affected the overall quality of the public authority websites. Other essential criteria included website content and technical performance. Fuzzy AHP was also applied in conducting a usability evaluation on e-government websites from a study by Lamichhane and Meesad (2011). It was based on four criteria and five websites were used as alternatives. Relevance and complete information about the services were found to be the most important sub-criteria.

Burmaoglu and Kazancoglu (2012) evaluated e-government websites in Turkey using fuzzy AHP and fuzzy VIKOR. It was based on three criteria of e-democracy, e-service and website design. These were subdivided further into different sub-criteria. The study concluded by recommending that e-service applications must be developed by different countries. Dominic et al. (2011) compared e-government websites in five Asian countries using a 
combination of Linear Weightage Model (LWM), fuzzy AHP, AHP, and a new hybrid model (NHM). The results of the study confirmed that quality and performance criteria were neglected by most Asian e-government websites.

\section{MCDM Approach in Travel Website Usability and Quality Evaluation}

Another important genre of websites are travel websites. A study by Kabir and Hasin (2012) examined important factors in the website quality of travel agencies based on user perception. The study further explored the use of MADM approaches to evaluate the service quality of travel websites. Five criteria grouped into 17 sub-criteria were used to develop the model. Soleymaninejad et al. (2016) evaluated two travel agent websites based in the USA using TOPSIS and six criteria in the study. Results from the study showed that the most important criteria were visibility, findability, functionality and accessibility. Furthermore, Khan and Dominic (2013) evaluated the website quality of four Malaysian airline websites using AHP based on criteria generated from web diagnostic online. The best airline with the most quality website was obtained at the end of the study.

Wen-Hsien et al. (2009) developed a model using DEMATEL ANP and VIKOR to evaluate five airline websites in Taiwan. The study concluded that Taiwanese airlines did not utilize the full potential of the Internet. It was also discovered that all the five websites did not perform well in price negotiation, low price, responsiveness and communication. Studies by Kabir and Sutana (2013) considered users' viewpoint in evaluating major factors of travel agency websites. Fuzzy TOPSIS was used for the evaluation. Hu (2009) developed a genetic-algorithm methodology to determine the degree of importance of respective criteria from fuzzy MCDM. Four representative travel websites in Taiwan were selected to determine the critical criteria of customers' concerns. A study by Lee et al. (2012) proposed a hierarchical MCDM evaluation model based on fuzzy AHP and fuzzy TOPSIS methods to evaluate the quality of four travel websites in Taiwan based on five aspects which was further subdivided into 17 criteria.

Another research proposed a fuzzy MCDM model to formulate the problem of travel website evaluation (Law, 2007). Dominic and Jati (2011) and Khan and Dominic (2013) in their studies developed MCDM models to measure the quality of Asian airline websites via web diagnosis tools by using AHP, FAHP and Linear Weighted Model (LWM). The newly proposed method was found to be effective in measuring the quality of airline websites.

\section{MCDM Approach in other Website Genres}

Other website genres where MCDM approach has been applied are discussed as follows. Zhang et al. (2015) conducted usability evaluation on four 
ecological park websites using a model that was based on an index layer, criterion layer and target layer. Three criteria of topicality, functionality and information elements were selected by using Group AHP. Presley and Fellows (2013) used AHP to evaluate the usability of three financial portals in the USA based on five criteria and 14 sub-criteria. The order of the importance of criteria was the ease of use, content, made-for-the-media, emotion and promotion. From the sub-criteria level, the three highest weighting were structure, goals and feedback. Aytuna et al. (2012) developed a model based on AHP to evaluate political websites in Turkey using five criteria which were functionality, efficiency, usability, reliability and interactivity. Findings from the study indicated that functionality and visibility were the main goals of the websites of Turkish political parties, with interactivity showing the lowest weighting.

Alptekin et al. (2015) proposed the use of fuzzy TOPSIS method to evaluate the quality of five Turkish bookstore websites. Four criteria which were further categorised into 15 subcategories were used in the evaluation. Mirbargkar and Zadmehr (2015) investigated the quality of three hospital websites using ANP and fuzzy TOPSIS. Six major criteria and 19 sub-criteria were used. The results indicated that information quality criteria was ranked first. This was followed by assurance and the least was responsiveness. From the sub-criteria, information accuracy and trust were ranked first and second, respectively, with customisation ranked last. Tsai et al. (2010) used a combination of DEMATEL ANP, VIKOR and Weight Variance Analysis (WVA) to evaluate the quality of seven national park websites in Taiwan. Djordj et al. (2013) employed the use of ANP to measure the relative importance of usability factors of a defence ministry portal in Serbia. Three factors: usability, safety and flexibility were used for the analysis in the study.

Bijan and Salehi (2013) in their study proposed a model to compare customer satisfaction indices of two e-recruitment websites in order to select the most preferred website in a specific context. The model was developed by merging the ANP approach with the America Customer Satisfaction Index (ACSI) for e-commerce. Kaya and Kahraman (2011) developed an assessment methodology for four e-banking websites using an integrated fuzzy AHPELECTRE approach. The criteria used were: information system (IS) quality, reliability, competence, access, customer service quality, security, ease-ofuse and product quality. An evaluation model to measure the performance of hospital websites based on quality by using two MCDM methods: AHP and PROMETHEE were developed by Bilsel et al. (2006). It consisted of seven e-service quality dimensions which were used to test the model.

Kaya (2010) proposed a methodology for e-business website quality based on a multi-attribute approach. The model involved the use of a modified fuzzy TOPSIS approach, where a fuzzy AHP procedure was used to determine 
the weight of the evaluation criteria. Chou and Cheng (2012) developed a hybrid approach combining fuzzy ANP and fuzzy to evaluate the website quality of four certified professional accounting firms in Taiwan. Three criteria were used in the study which were further subdivided into 12 sub-criteria. The results showed that richness, comprehensibility, assurance, relevance, and reliability were the top five priorities.

Another important area where the MCDM approach has been widely used is in hotels and tourism. Akincilar and Dagdeviren (2014) evaluated fivestar hotels in Ankara, Turkey using AHP and PROMETHEE. The quality of e-service of four hotels using Webqual and fuzzy AHP was also conducted by Shahin et al. (2014). Three criteria were used in the study and it was found that the highest priority was information quality followed by usability dimensions and service interaction. In another study, fuzzy TOPSIS was used to evaluate and compare the ability and functionality of hotel websites in China based on usability. Four criteria: navigation, website friendliness (ease of use), language and overall layout were further subdivided into 25 sub-criteria which were used in the study (Qi, Law, \& Buhalis, 2017b). Calisir et al. (2009) in their study used ANP to determine the relative importance of usability and functionality factors using two online auction and shopping websites as case studies. The findings revealed that users of these websites gave higher priority to usability than to functionality factors. More so, navigation and interaction were found to be factors of high relative importance.

\section{ANALYSIS AND RESULTS}

This section discusses the classification based on the following: year of publication, the genre of websites, MCDM methods employed, number of criteria used in the studies and location of websites by country.

\section{Distribution of Academic Papers Based on Year of Publication}

RQ1: What is the number of studies undertaken in the evaluation of website quality and usability using the MCDM approach over the years?

Figure 3 provides information about frequency distribution by publication rate based on the number of articles per year. Fewer articles were published in the earlier years (2005-2009). However, there has been considerable growth in the number of papers on MCDM approaches in terms of website quality and usability evaluation since 2010. The highest number of articles was published in 2017 and $61 \%$ of the total number of articles have been published since 2010. There is an expectation that more articles would be published in subsequent years. 


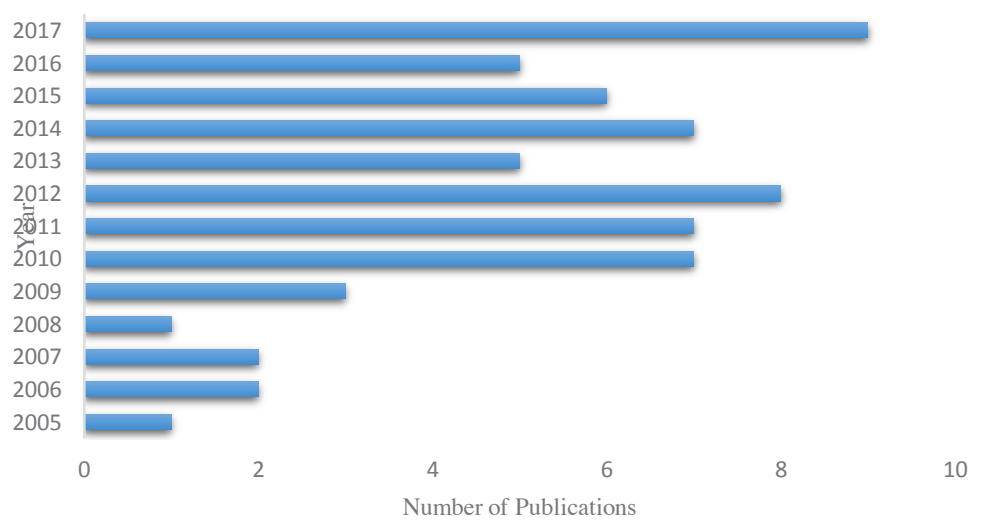

Figure 3. Distribution of publications based on year

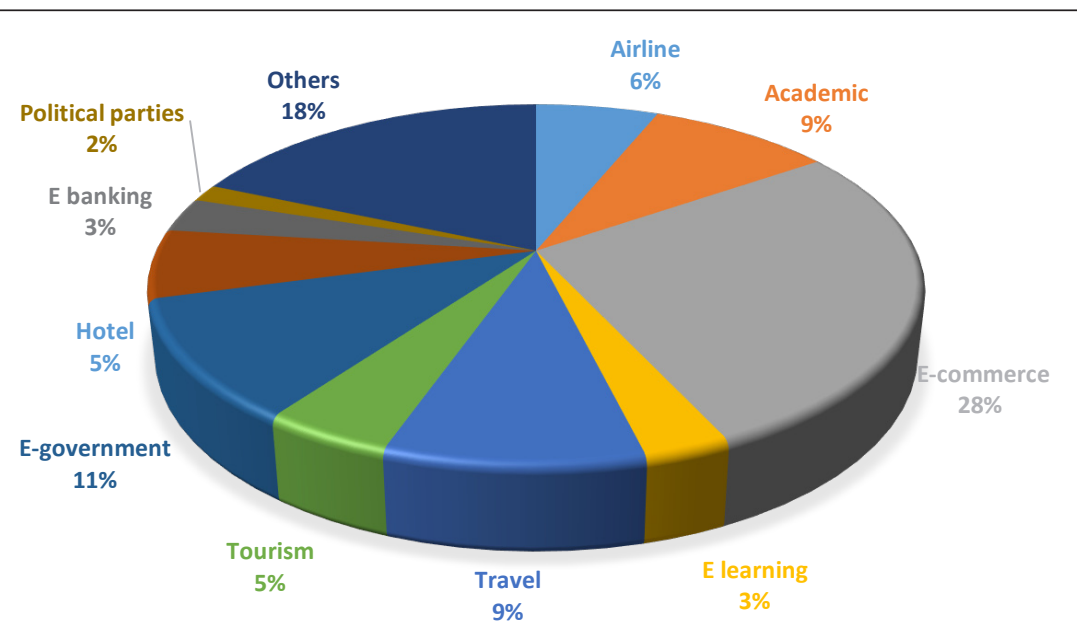

Figure 4. Distribution according to website genres.

\section{Distribution of Academic Papers Based on Website Genre}

RQ2 : What is the genre of websites which most commonly apply MCDM methods?

Figure 4 shows the distribution according to the genre of websites. Websites from different domains like education, business, government, hospitality, tourism and agriculture have been used in previous studies over the years. The use of MCDM in e-commerce websites in terms of usability and quality takes the lead, as $28 \%$ of the reviewed papers focused on them. This is followed by 
e-government (11\%), travel (9\%), academic websites $(9 \%)$, airline $(6 \%)$, hotel $(5 \%)$, tourism $(5 \%)$, e-learning $(3 \%)$, e-banking $(3 \%)$ and political parties $(2 \%)$. This implies that the studies have cut across virtually every genre of websites except religious organisation websites.

\section{Distribution of Academic Papers Based on MCDM Approach}

RQ3: What are the MCDM approaches used in website usability and quality evaluation?

Figure 5 shows the distribution based on the MCDM approaches used in the reviewed papers. It can be seen from the figure that the fuzzy AHP approach is the most popular MCDM approach used in website usability and quality evaluation. It has slightly taken over the AHP approach due to its integration with fuzzy logic. It can also be observed that AHP and FAHP are mostly integrated with other methods in order to provide a better model and better results. Previous studies have also made this observation (Kubler et al., 2016; Mardani, et al., 2015; Zare et al., 2016). Another observation is that there is a proliferation of new approaches being developed in conjunction with soft computing techniques. The common trend, however, is that most of these methods are integrated with each other. This is necessary in order to handle different operations being performed with different MCDM methods like selection, ranking and prioritisation. Table 3 further gives a breakdown of the papers showing the associated authors with the MCDM approach used in various studies including TrIFMAGDM, a triangular intuitionistic fuzzy multiple attribute group decision-making.

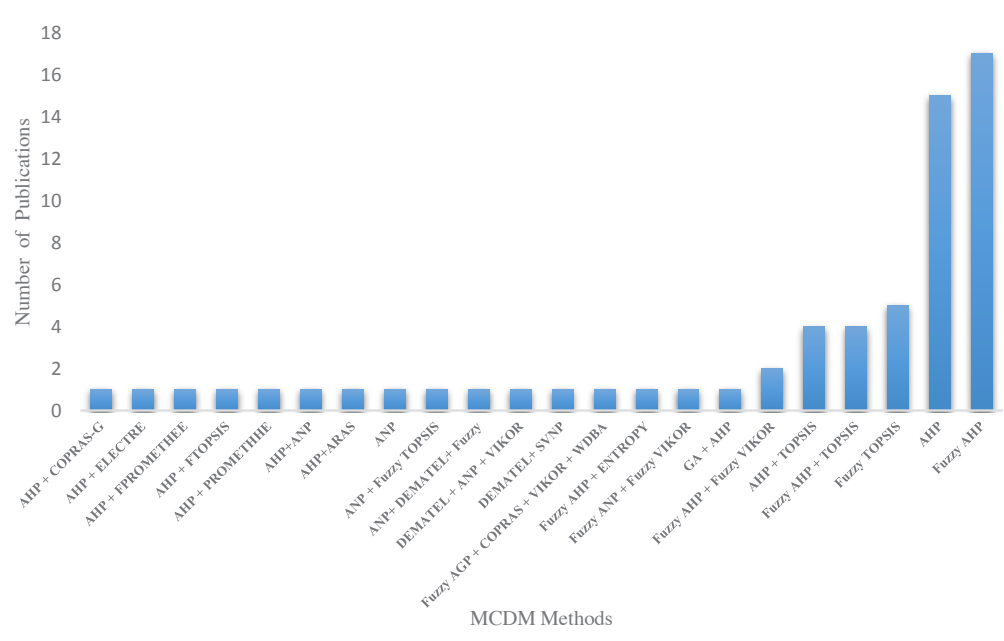

Figure 5. Number of publications based on MCDM approach(s). 
Table 3

Publications by authors based on MCDM approaches

\begin{tabular}{|c|c|}
\hline Method/Approach & Author(s) \\
\hline AHP & $\begin{array}{l}\text { Aytuna et al. (2012), Khan and Dominic (2013), Byun } \\
\text { and Finnie (2011), Roy et al. (2016), Presley and } \\
\text { Fellows (2013), Younghwa and Kenneth (2006), Roy } \\
\text { et al. (2016), Zhang et al. (2015), Delice and Gungor } \\
\text { (2009), Guimei and Taowei (2012), Kostoglou et al. } \\
\text { (2014), Pathania and Rasool (2017). }\end{array}$ \\
\hline ANP & Djordj et al. (2013). \\
\hline $\begin{array}{l}\text { DEMATEL \&ANP\& } \\
\text { Fuzzy }\end{array}$ & Kabak and Burmaoğlu (2013). \\
\hline Fuzzy AHP & $\begin{array}{l}\text { Dominic et al. (2011), Yi-wen et al. (2007), Liu and } \\
\text { Zhang (2011), Lin (2010), Markaki, Charilas, and } \\
\text { Askounis (2010), Vatansever and Akgu (2014), Shahin } \\
\text { et al. (2014), Aydin and Kahraman (2011), Dominic and } \\
\text { Jati (2010), Kong and Liu (2005), Nagpal et al. (2015 } \\
\text { a). }\end{array}$ \\
\hline AHP \&TOPSIS & Soleymaninejad, Shadifar, and Karimi (2016). \\
\hline AHP \& ELECTRE & Kaya and Kahraman (2011). \\
\hline AHP \& PROMETHHE & Akincilar and Dagdeviren (2014). \\
\hline AHP \& COPRAS-G & Ecer (2014). \\
\hline Fuzzy TOPSIS & $\begin{array}{l}\text { Kabir and Hasin (2012), Alptekin et al. (2015). Sun } \\
\text { and Lin (2009), Büyüközkan et al. (2010), Qi et al. } \\
\text { (2017). }\end{array}$ \\
\hline Fuzzy AHP \& TOPSIS & $\begin{array}{l}\text { Lee et al. (2012), Masudin and Saputro (2016), Kaya } \\
\text { (2010), Kaya (2010), Nagpal et al. (2015b). }\end{array}$ \\
\hline Fuzzy AHP \&Fuzzy & Burmaoglu and Kazancoglu (2012), Aydin and \\
\hline VIKOR & Kahraman (2012). \\
\hline Fuzzy ANP \& & Chou and Cheng (2012). \\
\hline FuzzyVIKOR & \\
\hline AHP \& PROMETHEE & Bilsel et al. (2006). \\
\hline AHP \& FTOPSIS & Yu et al. (2011). \\
\hline FAHP \&COPRAS & Garg and Jain (2017). \\
\hline$\& V I K O R \&$ WDBA & \\
\hline GA \&AHP & $\mathrm{Hu}(2009)$ \\
\hline ANP \& Fuzzy TOPSIS & Mirbargkar and Zadmehr (2015), Dey et al. (2015). \\
\hline Fuzzy AHP+ENTROPY & Nagpal et al. (2016). \\
\hline $\begin{array}{l}\text { DEMATEL \& ANP \& } \\
\text { VIKOR }\end{array}$ & Tsai et al. (2010). \\
\hline
\end{tabular}

(continued) 


\begin{tabular}{ll}
\hline \multicolumn{1}{c}{ Method/Approach } & \multicolumn{1}{c}{ Author(s) } \\
\hline SVTN-DEMATEL & Liang et al. (2017). \\
NS (FUZZY MCDM) & $\begin{array}{l}\text { Pearson and Pearson (2008), Law (2007), Castro- } \\
\text { Lopez et al. (2017). }\end{array}$ \\
TrIFMAGDM & Lian et al. (2016). \\
\hline
\end{tabular}

\section{Distribution of Academic Papers Based on the Number of Criteria Used}

RQ4: What is the number of criteria often used in MCDM methods?

Another important trend to know is the number of criteria used in the studies. This is very important as MCDM works based on criteria and in some cases, are further divided into sub-criteria. Figure 6 shows the number of criteria used in both website quality and usability evaluation studies. The most commonly used number of criteria as observed from the study is five while the maximum number of criteria used is 12. Saaty and Ozdemir (2003) in their study, suggested that the number of criteria should not be more than the magic number seven plus or minus two. This is to reduce the effect of too much cognitive load on human computational ability. It was affirmed that humans could judge criteria using pairwise comparison with a few errors if the set criteria were limited. This assertion is further corroborated by Byun and Finnie (2011).

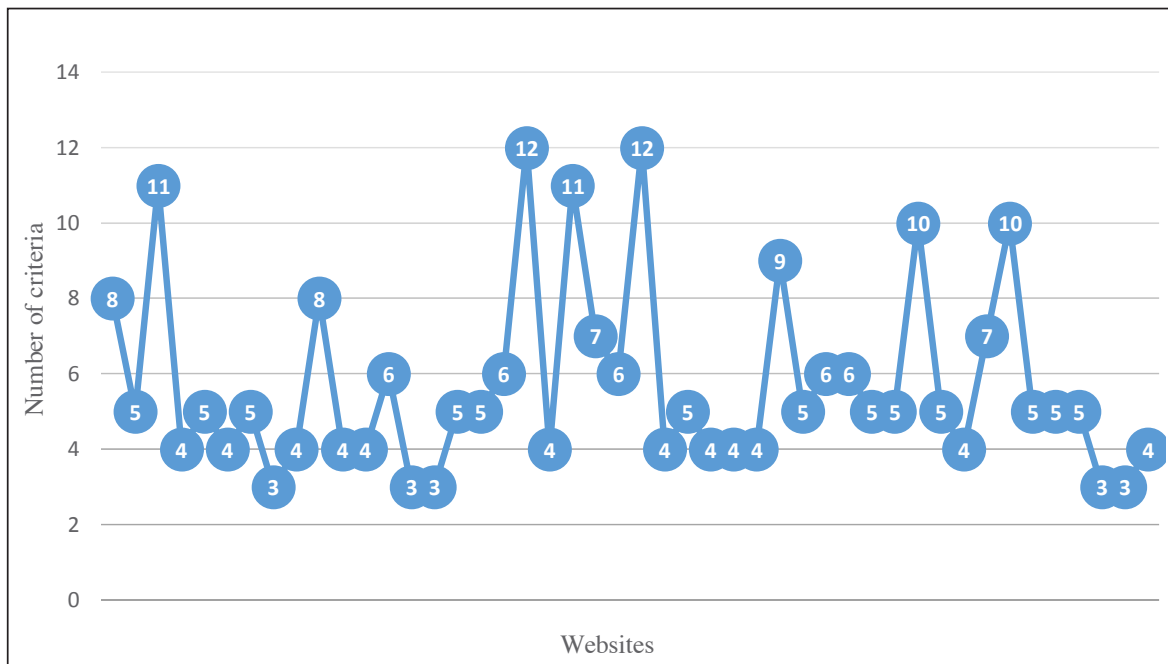

Figure 6. Number of criteria used in each website focused on website quality. 


\section{Distribution of Academic Papers Based on Website Location by Country}

RQ 5: What is the location of the websites by country used in the studies? Distribution of academic papers based on the countries in which websites are used is shown in Figure 7. It presents the countries where websites are used to conduct research on website quality and usability evaluation using the MCDM approach. In this study, attention was focused on website affiliation rather than author affiliation as has been done in some previous work (Behzadian, Khanmohammadi, Morteza, \& Ignatius, 2012; Mardani, Jusoh, Zavadskas, \& Nor, 2015). Websites from 18 countries were used in the studies under review. From the geographic distribution based on the countries in Figure 7, websites from Turkey (25\%) takes the lead followed by India (18\%), China (12\%) and Taiwan (10\%), respectively.

Further, it was observed that in most cases, the author's country of affiliation was also the same as the website's affiliation. Therefore, most of the websites frequently used in the studies were from the Asian continent. In contrast, there was virtually none from the African continent. Perhaps some studies could have been retrieved from countries like France, Iran and Japan; however this was not possible due to the English language exclusion criteria used in these studies. Figure 7 clearly shows that authors from Asia and especially Turkey, are active in MCDM research. A similar trend on the dominance of the Asian continent in publications on MCDM applications was observed by Behzadian et al. (2012) and Mardani et al. (2015) where it was reported that most of the authors from the study were from Taiwan, China and Turkey, respectively.

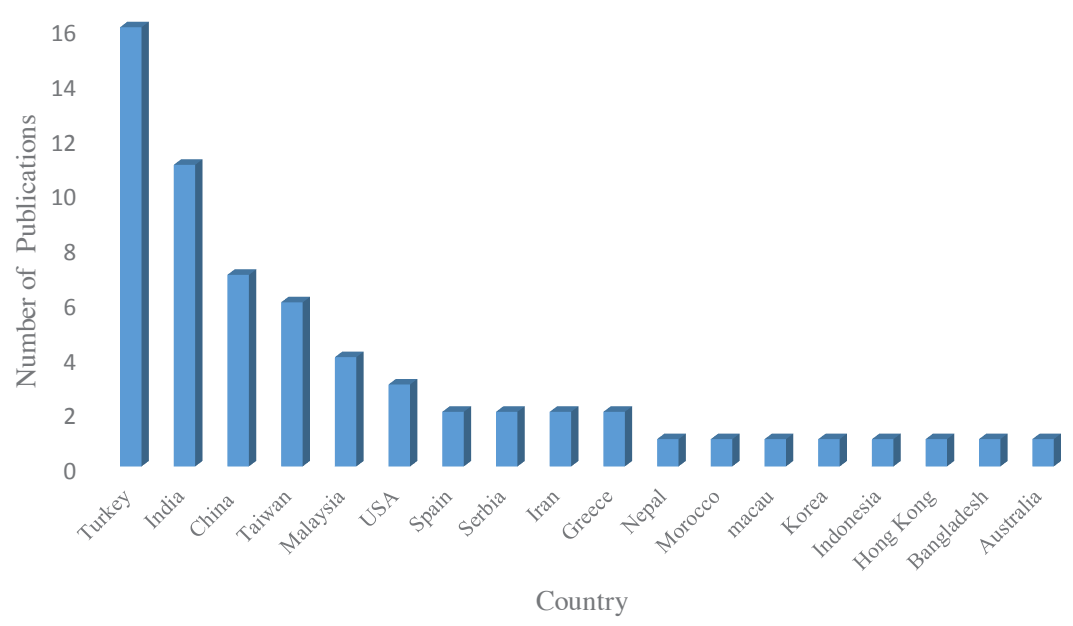

Figure 7. Distribution of publications based on website location by country. 


\section{CONCLUSION AND RECOMMENDATIONS}

This paper has presented an extensive review of the literature on MCDM approaches in terms of website usability and quality evaluation. A total of 63 scholarly articles retrieved from reputable journals and conference proceedings were carefully analysed. From the review, a variety of individual and integrated methods were proposed for website quality and usability evaluation. On the whole, most studies focused on the aspect of website quality compared to studies on the usability aspect which is relatively small but growing. Thus not much work has been conducted in website usability using MCDM approaches as compared to website quality. The most popular methods are AHP and fuzzy integrated with AHP, and five is mostly the number of criteria used in the studies. Besides, there are more studies on e-commerce websites than any other genre of websites. Despite the popularity of academic websites, not much attention has been devoted to these websites from the MCDM perspective.

In addition, some websites such as political and religious websites are not well represented. The most popular criterion from a quality perspective is usability, although the most important criteria from a usability perspective are ease of use and navigability. More so, most studies are from websites affiliated with Turkey followed by India. On the other hand, there is a dearth of studies from African countries and hence the quality and usability of their websites are not adequately represented and studied. Furthermore, integrating MCDM methods with artificial intelligence techniques like Artificial Neural Network (ANN) and genetic algorithms (GP) although gaining popularity in other areas has yet to be widely applied in website usability and quality evaluation. In an area like MCDM application to supplier selection and evaluation, AHP-GP is the most popular integrated approach (Ho et al., 2010).

One of the limitations of this study is that the results are based on data obtained from scholarly journals and conferences. These do not include masters theses, doctoral dissertations, textbooks, and unpublished working papers in the MCDM literature. Besides, only articles published in English were used, hence publications in other languages were not considered. The focus was on the quality and usability aspects of the websites, thus other aspects like functionality, maintainability, efficiency and security could be considered in future studies. Therefore, further studies that include all these aspects and other databases not covered could be considered as well.

\section{ACKNOWLEDGMENT}

This research receives no specific grant from any funding agency in the public, commercial or not-for-profit sectors. 


\section{REFERENCES}

Adepoju, S. A., Oyefolahan, I. O., Abdullahi, M. B., \& Mohammed, A. A. (2018a). A survey of research trends on University Websites' Usability Evaluation. In 2nd International Conference on Information and Communication Technology and Its Applications (pp. 127-132).

Adepoju, S. A., Oyefolahan, I. O., Abdullahi, M. B., \& Mohammed, A. A. (2018b). Integrated usability evaluation framework for university websites. I-Manager's Journal on Information Technology, 8(1), 1927.

Agirgun, B. (2012). Ranking B2C web sites with AHP and TOPSIS under fuzzy environment. Nevşehir Üniversitesi Fen Bilimleri Enstitü Dergisi, 1(2), 65-78. Retrieved from http://dergipark.ulakbim.gov.tr/nevbiltek/ article/view/1035000106

Akincilar, A., \& Dagdeviren, M. (2014). A hybrid multi-criteria decision making model to evaluate hotel websites. International Journal of Hospitality Management, 36, 263-271. https://doi.org/10.1016/j. ijhm.2013.10.002

Alptekin, N., Hall, E. E., \& Sevim, N. (2015). Evaluation of websites quality using fuzzy TOPSIS method. International Journal of Academic Research in Business and Social Sciences, 5(8), 221-242. https://doi. org/10.6007/IJARBSS/v5-i8/1778

Asemi, A., Sapiyan, M., Asemi, A., \& Haji, R. B. (2013). Fuzzy multi criteria decision making applications : A review study. Retrieved from http:// eprints.um.edu.my/12976/

Aydin, S., \& Kahraman, C. (2011). A modified fuzzy analytic hierarchy process based multicriteria decision making methodology for assessing e-commerce website quality : A case study in Turkey. In World Congress on Engineering 2011 (Vol. II, pp. 5-9). London, UK. Retrieved from http://iaeng.org/publication/WCE2011/WCE2011_pp1174-1178.pdf

Aydin, S., \& Kahraman, C. (2012). Evaluation of e-commerce website quality using fuzzy multi-criteria decision making approach. $A E N G$ International Journal of Computer Science, 39(1). Retrieved from https://pdfs.semanticscholar.org/d17a/92e66a83ff08cd5fbd4de87d954 $4 \mathrm{c} 5 \mathrm{fc} 75 \mathrm{c} 7 . \mathrm{pdf}$

Aytuna, N., Karsak, B., \& Albayrak, Y. E. (2012). A proposed model for the Turkish political parties web sites' efficiency: An integrated method using analytic hierarchy process. International Journal of Information Technology and Business Management, 8(1), 55-72.

Bali, O., Burmaoğlu, S., \& Kazançoğlu, Y. (2010). Performance evaluation of transportation websites by using fuzzy AHP. In International logistics and supply chain congress. Istanbul, Turkey. 
Behzadian, M., Kazemzadeh, R. B., Albadvi, A., \& Aghdasi, M. (2010). PROMETHEE : A comprehensive literature review on methodologies and applications. European Journal of Operational Research, 200(1), 198-215. https://doi.org/10.1016/j.ejor.2009.01.021

Behzadian, M., Khanmohammadi, S., Morteza, Y., \& Ignatius, J. (2012). A state-of the-art survey of TOPSIS applications. Expert Systems with Applications, 39(17), 13051-13069. https://doi.org/10.1016/j. eswa.2012.05.056

Bijan, Y., \& Salehi, M. (2013). Comparison of user satisfaction of ecommerce websites by the analytic network process. International Journal of the Analytical Hierarchy Process, 5(2), 223-251. Retrieved from http:// ijahp.org/index.php/IJAHP/article/view/180

Bilsel, R. U., Büyüközkan, G., \& Ruan, D. (2006). A fuzzy preference-ranking model for a quality evaluation of hospital web sites. International Journal Of Intelligent Systems, 21(21), 1181-1197. https://doi. org/10.1002/int.20177

Blagec, K., Romagnoli, K. M., Boyce, R. D., \& Samwald, M. (2016). Examining perceptions of the usefulness and usability of a mobile-based system for pharmacogenomics clinical decision support: A mixed methods study. PeerJ, 4, 1-24. https://doi.org/10.7717/peerj.1671

Burmaoglu, S., \& Kazancoglu, Y. (2012). E-government website evaluation with hybrid MCDM method in fuzzy environment. International Journal Applied Decision Sciences, 5(2), 163-181. https://doi.org/10.1504/ IJADS.2012.046504

Büyüközkan, G., Arsenyan, J., \& Ertek, G. (2010). Evaluation of e-learning web sites using fuzzy axiomatic design based approach. International Journal of Computational Intelligence Systems, 3(1), 28-42. https:// doi.org/10.1080/18756891.2010.9727675

Byun, D., \& Finnie, G. (2011). An AHP method for evaluating usability of electronic government portals. Electronic Government, An International Journal, 8(4), 343-362. https://doi.org/https://doi.org/10.1504/ EG.2011.042811

Calisir, F., Bayraktaroglu, A. E., Gumussoy, C. A., Topcu, Y. I., \& Mutlu, T. (2009). The relative importance of usability and functionality factors for online auction and shopping web sites. Online Information Review, 34(3), 420-439. https://doi.org/10.1108/14684521011037025

Castro-Lopez, A., Puente, J., \& Vazquez-Casielles, R. (2017). Fuzzy inference suitability to determine the utilitarian quality of B2C websites. Applied Soft Computing Journal, 57, 132-143. https://doi.org/10.1016/j. asoc.2017.03.039

Ceballos, B., Teresa, M., \& David, L. (2016). A comparative analysis of multicriteria decision-making methods. Progress in Artificial Intelligence. https://doi.org/10.1007/s13748-016-0093-1 
Çelik, P., \& Cansu, G. K. (2017). Fuzzy AHP-fuzzy PROMETHEE approach in evaluation of e-service quality: Case of airline web sites. The Journal of International Social Research, 10(52), 1003-1013. https://doi. org/10.17719/jisr.2017.1954

Chou, W., \& Cheng, Y. (2012). A hybrid fuzzy MCDM approach for evaluating website quality of professional accounting firms. Expert Systems With Applications, 39(3), 2783-2793. https://doi.org/10.1016/j. eswa.2011.08.138

Das, T., \& Patil, S. R. (2014). A review of current trends in usability evaluation methods. International Journal of Engineering Research \& Technology (IJERT), 3(9), 837-840.

Delice, E. K., \& Gungor, Z. (2009). The usability analysis with heuristic evaluation and analytic hierarchy process. International Journal of Industrial Ergonomics, 39, 934-939. https://doi.org/10.1016/j. ergon.2009.08.005

Dey, S., Jana, B., Gourisaria, M. K., Mohanty, S. N., \& Chatterjee, R. (2015). Evaluation of Indian B2C e-shopping websites under multi criteria decision-making using fuzzy hybrid technique. International Journal of Applied Engineering Research, 10(9), 24551-24580.

Diaby, V., Campbell, K., \& Goeree, R. (2013). Multi-criteria decision analysis ( MCDA ) in health care : A bibliometric analysis. Operations Research for Health Care, 2(1-2), 20-24. https://doi.org/10.1016/j. orhc.2013.03.001

Diniz, E., Porto, R. M., \& Adachi, T. (2005). Internet Banking in Brazil : Evaluation of functionality, reliability and usability. Electronic Journal of Information Systems Evaluation Volume, 8(1), 41-50.

Djordj, N. D., Rančić, D. D., \& Vulić, I. (2013). The relative importance of the usability factors for web portals. In Telecommunication in Modern Satellite, Cable and Broadcasting Services (TELSIKS) (pp. 571-574). Serbia: IEEE. https://doi.org/10.1109/TELSKS.2013.6704443

Dodgson, J. S., Spackman, M., Pearman, A., \& Phillips, L. D. (2009). Multicriteria analysis : A manual. London: Department for Communities and Local Government.

Dominic, P. D. D., Jati, H., \& Hanim, S. (2013). University website quality comparison by using non-parametric statistical test: A case study from Malaysia. International Journal of Operational Research, 16(3), 349374. https://doi.org/https://doi.org/10.1504/IJOR.2013.052335

Dominic, P. D. D., \& Jati, H. (2010). Evaluation method of Malaysian university website : Quality website using hybrid method. In Information Technology International Symposium (ITSim) (pp. 1-6). Kuala Lumpur, Malaysia: IEEE. https://doi.org/10.1109/ITSIM.2010.5561363

Dominic, P. D. D., \& Jati, H. (2011). A comparison of Asian airlines websites quality: Using a non-parametric test. International Journal of Business Innovation and Research, 5(5), 599-623. 
Dominic, P. D. D., Jati, H., \& Kannabiran, G. (2010). Performance evaluation on quality of Asian e-government websites - an AHP approach. International Journal of Business Information Systems, 6(2), 219-239.

Dominic, P. D. D., Jati, H., \& Sellappan, P. (2011). A comparison of Asian e-government websites quality: Using a non-parametric test. International Journal of Business Information Systems, 7(2), 220-246. https://doi.org/https://doi.org/10.1504/IJBIS.2011.038513

Ecer, F. (2014). A hybrid banking websites quality evaluation model using AHP and COPRAS-G : A Turkey case. Technological and Economic Development of Economy, 20(4), 758-782. https://doi.org/10.3846/20 294913.2014.915596

Federici, S., \& Borsci, S. (2017). Usability evaluation : Models, methods, and applications. In International Encyclopedia of Rehabilitation 2010 (pp. 1-17). Retrieved from http://cirrie.buffalo.edu/encyclopedia/en/ article/277/

Fernandez, A., Insfran, E., \& Abrahão, S. (2011). Usability evaluation methods for the web: A systematic mapping study. Information and Software Technology, 53(8), 789-817. https://doi.org/10.1016/j. infsof.2011.02.007

Garg, R., \& Jain, D. (2017). Fuzzy multi-attribute decision making evaluation of e-learning websites using FAHP, COPRAS, VIKOR, WDBA. Decision Science Letters 6, 351-364. https://doi.org/10.5267/j.dsl.2017.2.003

Govindan, K., \& Jepsen, M. B. (2015). ELECTRE: A comprehensive literature review on methodologies and applications. European Journal of Operational Research, 250(1), 1-29. https://doi.org/10.1016/j. ejor.2015.07.019

Grigera, J., Garrido, A., Zaraté, P., Camilleri, G., Fernández, A., Dria, A., ... Cedex, T. (2018). A mixed usability evaluation on a multi criteria group decision support system in agriculture. In Interactiion. ACM. Retrieved from https://doi.org/10.1145/3233824.3233852

Guimei, Z., \& Taowei, Y. (2012). A quantitative research into the usability evaluation of China's e-government websites. In 2nd International Congress on Computer Applications and Computational Science (pp. 437-442). Berlin Heidelberg: Springer. Retrieved from https://link. springer.com/chapter/10.1007/978-3-642-28314-7_58

Gupta, S. (2015). A comparative study of usability evaluation methods. International Journal of Computer Trends and Technology, 22(3), 103-106. Retrieved from http://www.ijcttjournal.org/2015/Volume22/ number-3/IJCTT-V22P121.pdf

Ho, W., Xu, X., \& Dey, P. K. (2010). Multi-criteria decision making approaches for supplier evaluation and selection: A literature review. European Journal of Operational Research, 202(1), 16-24. https://doi. org/10.1016/j.ejor.2009.05.009 
Hu, Y. (2009). Fuzzy multiple-criteria decision making in the determination of critical criteria for assessing service quality of travel websites. Expert Systems With Applications, 36(3), 6439-6445. https://doi.org/10.1016/j. eswa.2008.07.046

Jain, D., Garg, R., \& Bansal, A. (2015). A parameterized selection and evaluation of e-learning websites using topsis method. International Journal of Research \& Development in Technology and Management Science-Kailash, 22(3), 12-26. Retrieved from http://journal.rtmonline. in/vol22iss3/0530111.pdf

Jaroslaw, W., Paweł, Z., \& Jarosław, J. (2016). PEQUAL - E-commerce websites quality evaluation methodology. In Computer Science and Information Systems (FedCSIS), 2016 Federated (Vol. 8, pp. 13171327). Gdansk, Poland. https://doi.org/10.15439/2016F469

Kabak, M., \& Burmaoğlu, S. (2013). A holistic evaluation of the e-procurement website by using a hybrid MCDM methodology. Electronic Government, An International Journal, 10(2), 125-150. https://doi.org/https://doi. org/10.1504/EG.2013.052598

Kabir, G., \& Hasin, M. A. A. (2012). Comparative analysis of topsis and fuzzy topsis for the evaluation of travel website service quality. International Journal for Quality Research, 6(3), 169-185.

Kabir, G., \& Sutana, R. (2013). Evaluation of travel website service quality using fuzzy topsis. Suranaree Journal of Science and Technology, 20(1), 21-33. Retrieved from https://www.researchgate.net/publicatio $\mathrm{n} / 267240857 \% 0$ Aevaluation

Karabasevic, D., \& Stanujkic, D. (2019). An approach to evaluating the quality of websites based on the weighted sum preferred levels of performances. Acta Polytechnica Hungarica, 16(5), 195-215.

Kaya, T. (2010). Multi-attribute evaluation of website quality in e-business using an integrated fuzzy AHP TOPSIS methodology. International Journal of Computational Intelligence Systems, 3(3), 301-314. https:// doi.org/10.1080/18756891.2010.9727701

Kaya, T., \& Kahraman, C. (2011). A fuzzy approach to e-banking website quality assessment based on an integrated AHP-ELECTRE method. Technological and Economic Development of Economy, 17(2), 37-41. https://doi.org/10.3846/20294913.2011.583727

Kaya, T., \& Kahraman, C. (2013). A fuzzy approach to e-banking website quality assessment based on an integrated AHP-ELECTRE method. Technological and Economic Development of Economy, 17(2), 313334.

Khan, H., \& Dominic, P. D. D. (2013). Measuring quality of Asian airline websites using analytical hierarchy process: A future customer satisfaction approach. In Information Systems International Conference 
(ISICO) (pp. 67-72). Departemen Sistem Informasi, Institut Teknologi Sepuluh Nopember, Indonesia.

Kitchenham, B., \& Charters, S. (2007). Guidelines for performing systematic literature reviews in software engineering.

Kong, F., \& Liu, H. (2005). Applying fuzzy analytic hierarchy process to evaluate success factors of e-commerce. International Journal of Information and Systems Sciences, 1(3-4), 406-412. Retrieved from https://pdfs.semanticscholar.org/6d54/058dd182ca15403d4e99b105f8 52edbb5433.pdf

Kostoglou, V., Papathanasiou, J., \& Moschidis, O. (2014). A comparative analysis of Greek universities' presence on the World Wide Web using an analytical MCDM methodology. International Journal of Multicriteria Decision Making, 4(3), 279-298. https://doi.org/https:// doi.org/10.1504/IJMCDM.2014.064794

Kubler, S., Robert, J., Derigent, W., Voisin, A., \& Le, Y. (2016). A state-of the-art survey and testbed of fuzzy AHP (FAHP) applications. Expert Systems With Applications, 65, 398-422. https://doi.org/10.1016/j. eswa.2016.08.064

Lamichhane, R., \& Meesad, P. (2011). A usability evaluation for government websites of Nepal using fuzzy AHP. In M. Phayung (Ed.), I7th International Conference on Computing and Information Technology IC2IT2011 (pp. 99-104). Bangkok, Thailand.

Law, R. (2007). A fuzzy multiple criteria decision-making model for evaluating travel websites. Asia Pacific Journal of Tourism Research, 12(2), 147159. https://doi.org/10.1080/10941660701243372

Lee, C., Chiang, C., \& Chen, C. (2012). An evaluation model of e-service quality by applying hierarchical fuzzy topsis method. International Journal of Electronic Business Management, 10(1), 38-49. Retrieved from http://dblp.org/db/journals/ijebm/ijebm10.html

Lian, T., Yu, C., Wang, Z., \& Hou, Z. (2017). The evaluation study on tourism websites: From the perspective of triangular intuitionistic fuzzy multiple attribute group decision making. Journal of Applied Statistics, 44(16), 2877-2889. https://doi.org/10.1080/02664763.2016.1266466

Liang, R., Wang, J., \& Zhang, H. (2017). Evaluation of e-commerce websites: An integrated approach under a single-valued trapezoidal neutrosophic environment. Knowledge-Based Systems, 135, 44-59. https://doi. org/10.1016/j.knosys.2017.08.002

Lin, H. (2010). An application of fuzzy AHP for evaluating course website quality. Computers \& Education, 54(4), 877-888. https://doi. org/10.1016/j.compedu.2009.09.017

Liu, H., \& Zhang, S. (2011). Approach of fuzzy analytic hierarchy process to evaluate e-commerce websites, 248-252. Retrieved from http://elib. bsu.by/handle/123456789/10032 
Mardani, A., Jusoh, A., Nor, K., Khalifah, Z., \& Valipour, A. (2015). Multiple criteria decision-making techniques and their applications - a review of the literature from 2000 to 2014. Economic Research-Ekonomska Istraživanja, 28(1), 516-571. https://doi.org/10.1080/1331677X.2015. 1075139

Mardani, A., Jusoh, A., Zavadskas, E. K., \& Nor, K. (2015). Application of multiple-criteria decision-making techniques and approaches to evaluating of service quality: A systematic review of the literature. Journal of Business Economics and Management, 16(5), 1034-1068. https://doi.org/10.3846/16111699.2015.1095233

Mardani, A., Jusoha, A., \& Zavadskas, E. K. (2015). Fuzzy multiple criteria decision-making techniques and applications - Two decades review from 1994 to 2014. Expert Systems with Applications, 42(8), 41264148. https://doi.org/10.1016/j.eswa.2015.01.003

Mardani, A., Zavadskas, E. K., \& Govindan, K. (2016). VIKOR Technique : A systematic review of the state of the art literature on methodologies and applications. Sustainability, 8(37). https://doi.org/10.3390/su8010037

Markaki, O. I., Charilas, D. E., \& Askounis, D. (2010). Application of fuzzy analytic hierarchy process to evaluate the quality of e-government web sites. In Developments in E-systems Engineering (pp. 219-224). IEEE. https://doi.org/10.1109/DeSE.2010.42

Masudin, I., \& Saputro, T. E. (2016). Evaluation of B2C website based on the usability factors by using fuzzy AHP \& hierarchical fuzzy TOPSIS. IOP Conf. Series: Materials Science and Engineering, 114. https://doi. org/10.1088/1757-899X/114/1/012091

Mirbargkar, S. M., \& Zadmehr, O. (2015). Investigating the quality of electronic services using multiple attribute decision-making techniques case study (Aria , Ghaem, and Golsar Hospitals). Science Journal (CSJ), 36(6), 1233-1240. Retrieved from http://dergi.cumhuriyet.edu.tr/cumuscij/ article/view/5000139552

Mohsen, P., Madjid, T., Mimi, H. H., \& Majid, B. (2011). A taxonomy and review of the multiple criteria decision-making literature in chemical engineering. International Journal of Multicriteria Decision Making, 1(4), 407-467. Retrieved from https://doi.org/10.1504/ IJMCDM.2011.043556

Nagpal, R., Mehrotra, D., \& Bhatia, P. (2016). Usability evaluation of website using combined weighted method: Fuzzy AHP and entropy approach. International Journal of System Assurance Engineering and Management, 7(4), 408-417. https://doi.org/10.1007/s13198-0160462-y

Nagpal, R., Mehrotra, D., \& Bhatia, P. (2017). The state of art in website usability evaluation methods. In S. Saeed, Y. A. Bamarouf, T. Ramayah, 
\& S. Z. Iqbal (Eds.), Design Solutions for User-Centric Information Systems (Vol. 1, pp. 275-296). USA: IGI Global. Retrieved from http:// www.igi-global.com

Nagpal, R., Mehrotra, D., Bhatia, P., \& Sharma, A. (2015a). FAHP approach to rank educational websites on usability. International Journal of Computing and DigitalSystems, 4(4),251-260.https://doi.org/10.12785/ ijcds/040404

Nagpal, R., Mehrotra, D., Bhatia, P., \& Sharma, A. (2015b). Rank university websites using fuzzy AHP and Fuzzy TOPSIS approach on usability. International Journal of Information Engineering and Electronic Business, 10(1), 29-36. https://doi.org/10.5815/ijieeb.2015.01.04

Nawaz, A., \& Clemmensen, T. (2013). Website usability in Asia 'from within': An overview of a decade of literature. International Journal of HumanComputer Interaction, 29(4), 256-273. https://doi.org/https://doi.org/1 $0.1080 / 10447318.2013 .765764$

Nirmala, G., \& Uthra, G. (2017). Quality of online shopping websites in India : A study using intuitionistic fuzzy AHP. Journal of Advance Research in Dynamical \& Control Systems, 9(4), 117-124.

Pathania, A., \& Rasool, G. (2017). Investigating e tailer's perceived website quality using analytical hierarchy process technique. Procedia Computer Science, 122, 1016-1023. https://doi.org/10.1016/j.procs.2017.11.468

Paz, F., \& Pow-Sang, J. A. (2014). Current trends in usability evaluation methods: A systematic review. In 7th International Conference on Advanced Software Engineering and Its Applications (ASEA) (pp. 1115). IEEE. https://doi.org/10.1109/ASEA.2014.10

Pearson, J. M., \& Pearson, A. M. (2008). An exploratory study into determining the relative importance of key criteria in web usability : A multi-criteria approach. Journal of Computer Information Systems, 48(4), 115-127. https://doi.org/10.1080/08874417.2008.11646041

Perçin, S. (2017). Evaluating airline service quality using a combined fuzzy decision-making approach. Journal of Air Transport Management, 68, 48-60. https://doi.org/10.1016/j.jairtraman.2017.07.004

Percin, S., \& Aldalou, E. (2018). Financial performance evaluation of Turkish airline companies using integrated fuzzy AHP fuzzy topsis model, 583598. https://doi.org/10.18092/ulikidince.347925

Presley, A., \& Fellows, P. (2013). An analytic hierarchy process model for evaluating and comparing website usability. International Journal of Business Information Systems, 12(2), 123-139. https://doi.org/https:// doi.org/10.1504/IJBIS.2013.052047

Qi, S., Law, R., \& Buhalis, D. (2017a). Comparative evaluation study of the websites of China-based and international luxury hotels. Journal of China Tourism Research, 00(00), 1-25. https://doi.org/10.1080/19388 160.2017.1289135 
Qi, S., Law, R., \& Buhalis, D. (2017b). Comparative evaluation study of the websites of China-based and international luxury hotels. Journal of China Tourism Research, 13(1), 1-25. https://doi.org/10.1080/193881 60.2017.1289135

Quiñones, D., \& Rusu, C. (2017). How to develop usability heuristics : A systematic literature review. Computer Standards \& Interfaces, 53, 89-122. https://doi.org/10.1016/j.csi.2017.03.009

Rekik, R., Kallel, I., \& Alimi, A. M. (2016). Ranking criteria based on fuzzy ANP for assessing e-commerce web sites. In IEEE International Conference on Systems, Man, and Cybernetics (pp. 3469-3474). Hungary: IEEE. https://doi.org/10.1109/SMC.2016.7844770

Rekik, R., Kallel, I., Casillas, J., \& Alimi, A. M. (2016). Using multiple criteria decision making approaches to assess the quality of web sites. International Journal of Computer Science and Information Security, 14(7), 747-761.

Rekik, R., Kallel, I., Casillas, J., \& Alimi, A. M. (2018). Assessing web sites quality: A systematic literature review by text and association rues mining. International Journal of Information Management, 38(1), 201216. https://doi.org/10.1016/j.ijinfomgt.2017.06.007

Rekik, R., Kallell, I., \& Alimi, A. M. (2015). Quality evaluation of web sites : A comparative study of some multiple criteria decision making methods. In 1ntelliegent Systems Design and Applications (ISDA) 15th International Conference (pp. 585-590). Marrakech, Morocco: IEEE. https://doi.org/10.1109/ISDA.2015.7489183

Roy, Jagannath Kajal Chatterjee, K., Bandyopadhyay, A., \& Kar, S. (2018). Evaluation and selection of medical tourism sites: A rough Analytic Hierarchy Process based multi-attributive border approximation area comparison approach. Expert Systems, 35(1). https://doi.org/10.1111/ exsy. 12232

Roy, S., Kumar, P., \& Rajib, P. (2016). Quality assurance of academic websites using usability testing : An experimental study with AHP. International Journal of System Assurance Engineering and Management, 8(1), 1-11. https://doi.org/10.1007/s13198-016-0436-0

Roy, S., \& Pattnaik, P. K. (2014). Some popular usability evaluation techniques. In S. C. Satapathy, S. K. Udgata, \& B. N. Biswal (Eds.), FICTA 2013 (pp. 535-543). Switzerland: Springer International Publishing. https:// doi.org/10.1007/978-3-319-02931-3_61

Roy, S., Pattnaik, P. K., \& Mall, R. (2014). A quantitative approach to evaluate usability of academic websites based on human perception. Egyptian Informatics Journal. https://doi.org/10.1016/j.eij.2014.08.002

Saaty, T. L., \& Ozdemir, M. S. (2003). Why the magic number seven plus or minus two. Mathematical and Computer Modelling, 38, 233-244. 
Safari, H., \& Aghasi, E. (2014). Select a hypermarket location based on fuzzy multi criteria decision making (F-MCDM) techniques. Arabian Journal of Business and Management Review, 4(1), 76-95. Retrieved from https://search.proquest.com/openview/bf7c290421907d199c67262b7c 55a0de/1 ?pq-origsite $=$ gscholar $\& \mathrm{cbl}=1606372$

Sagar, K., \& Saha, A. (2017). Qualitative usability feature selection with ranking: A novel approach for ranking the identified usability problematic attributes for academic websites using data-mining techniques. HumanCentric Computing and Information Sciences, 7(1), 1-24. https://doi. org/10.1186/s13673-017-0111-8

Samanlioglu, F., \& Ayag, Z. (2018). A fuzzy AHP-VIKOR approach for evaluation of educational use simulation software packages. Journal of Intelligent \& Fuzzy Systems. https://doi.org/10.3233/JIFS-172290

Shahin, A., Pool, J. K., \& Poormostafa, M. (2014). Evaluating and ranking hotels offering e-service by integrated approach of Webqual and fuzzy AHP. International Journal of Business Information Systems, 15(1), 84-104. Retrieved from https://www.inderscienceonline.com/doi/ abs/10.1504/IJBIS.2014.057966

Si, S., You, X., Liu, H., \& Zhang, P. (2018). DEMATEL Technique: A systematic review of the state-of-the-art literature on methodologies and applications. Mathematical Problems in Engineering, (1). Retrieved from https://doi.org/10.1155/2018/3696457

Simon, N., Carbonera, B. J., \& Custodio, B. (2017). A comparative study on the usability of educational platforms used by instructors in the university of the Philippines. In I. K. Jussi, T. Barath, N. Salman, \& T. Andre (Eds.), Advances in Human Factors, Business Management, Training and Education (pp. 187-194). Springer Cham. https://doi.org/ https://doi.org/10.1007/978-3-319-42070-7_18

Soleymaninejad, M., Shadifar, M., \& Karimi, A. (2016). Evaluation of two major online travel agencies of US using TOPSIS method. Digital Technologies, 2(1), 1-8. https://doi.org/10.12691/dt-2-1-1

Speicher, M. (2015). What is Usability? A Characterization based on ISO 9241-11 and ISO/IEC 25010. ArXiv Preprint ArXiv, 1-10. Retrieved from http://arxiv.org/abs/1502.06792

Stanujkic, D., Paunovic, M., \& Stankovic, G. (2014). Multi-criteria model for evaluating quality of websites of the regional tourism organizations. In International Conference on Information and Software Technologies (pp. 311-316). Druskininka: Springer. https:// doi.org/10.13140/2.1.1498.7846

Stewart, T. (2012). Websites - quality and usability. Behaviour \& Information Technology, 31(7), 645-646. https://doi.org/10.1080/0144929X.2012.7 07372 
Sun, C., \& Lin, G. T. R. (2009). Using fuzzy TOPSIS method for evaluating the competitive advantages of shopping websites. Expert Systems With Applications, 36(9), 11764-11771. https://doi.org/10.1016/j. eswa.2009.04.017

Sun, S., Fong, D. K. C., Law, R., \& He, S. (2017). An updated comprehensive review of website evaluation studies in hospitality and tourism. International Journal of Contemporary Hospitality Management, 29(1), 355-373. https://doi.org/10.1108/IJCHM-12-2015-0736

Syke, H. S., Nina, D. N. B., Syke, J. M., \& Keune, H. (2013). Multi-criteria decision analysis ( MCDA) in ecosystem service valuation, 1, 1-6.

Tavana, M., Yazdani, M., \& Di-Caprio, D. (2017). An application of an integrated ANP-QFD framework for sustainable supplier selection. International Journal of Logisitics Research and Applications, 20(3), 254-275. https://doi.org/10.1080/13675567.2016.1219702

Tsai, W., Chou, W., \& Lai, C. (2010). An effective evaluation model and improvement analysis for national park websites : A case study of Taiwan. Tourism Management, 31(6), 936-952. https://doi.org/10.1016/j. tourman.2010.01.016

Ugras, T., Gulsecen, S., Cubukcu, C., Erdognus, I. 1li, Gashi, V., \& Bedir, M. (2016). Research trends in web site usability A sytematic review. pdf. In A. Marcus (Ed.), Design, User Experience and Usability. 5th International Conference of HCI International (pp. 517-528). Switzerland: Springer International Publishing.

Vatansever, K., \& Akgu, Y. (2014). Applying fuzzy analytic hierarchy process for evaluating service quality of private shopping website quality: A case study in Turkey. Journal of Business, Economics and Finance, 3(3), 283-301. Retrieved from http://dergipark.gov.tr/jbef/ issue $/ 32410 / 360451$

Velasquez, M., \& Hester, P. T. (2013). An analysis of multi-criteria decision making methods. International Journal of Operations Research, 10(2), $56-66$.

Wanke, P., Azad, A. K., Barros, C. P., \& Hadi-vencheh, A. (2015). Predicting performance in ASEAN banks: An integrated fuzzy MCDM-neural network approach. Expert Systems, 00(00). https://doi.org/10.1111/ exsy. 12144

Wardoyo, R., \& Wahyuningrum, T. (2018). University website quality ranking using logarithmic fuzzy preference programming. International Journal of Electrical and Computer Engineering, 8(5), 3349-3358. https://doi. org/10.11591/ijece.v8i5.pp3349-3358

Wen-Hsien, T., Jun-Der, L., \& Wen-Chin, C. (2009). The development of an evaluation model of e-commerce websites for the Taiwanese airline industry. Development, 1, 1-2009. Retrieved from https://pdfs. 
semanticscholar.org/234b/d3b742f7e678985549d56491a1fd48ee2581. pdf

Yi-wen, L., Kwon, Y., \& Kang, B. (2007). A fuzzy AHP approach to evaluating e-commerce websites. In Fifth International Conference on Software Engineering Research, Management and Applications (pp. 114-122). IEEE. https://doi.org/10.1109/SERA.2007.29

Younghwa, L., \& Kenneth, K. A. (2006). Investigating the effect of website quality on e-business success : An analytic hierarchy process ( AHP) approach. Decision Support Systems, 42, 1383-1401. https://doi. org/10.1016/j.dss.2005.11.005

Yu, X., Guo, S., Guo, J., \& Huang, X. (2011). Rank B2C e-commerce websites in e-alliance based on AHP and fuzzy TOPSIS. Expert Systems With Applications, 38(4), 3550-3557. https://doi.org/10.1016/j. eswa.2010.08.143

Zaim, H., Ramdani, M., \& Haddi, A. (2016). Multi-criteria analysis approach based on consumer satisfaction to rank B2C e-commerce websites. In 2016 11th International Conference on Intelligent Systems: Theories and Applications (SITA 2016). Mohammedia, Morocco: IEEE. https:// doi.org/10.1109/SITA.2016.7772260

Zare, M., Pahl, C., Rahnama, H., Nilashi, M., Mardani, A., Ibrahim, O., \& Ahmadi,H.(2016). Multi-criteriadecisionmakingapproachine-learning: A systematic review and classification. Applied Soft Computing Journal, 45, 108-128. https://doi.org/10.1016/j.asoc.2016.04.020

Zavadskas, K., Turskis, Z., \& Simona, K. (2014). State of art surveys of overviews on MCDM/MADM methods. Technological and Economic Development of Economy, 20(1), 165-179. https://doi.org/10.3846/202 94913.2014.892037

Zhang, Y., Zhao, X., Feng, L., \& Li, X. (2015). The usability evaluation of the ecological agriculture park website. International Journal of Multimedia and Ubiquitous Engineering, 10(12), 53-60. https://doi. org/http://dx.doi.org/10.14257/ijmue.2015.10.12.06

Zhou, X., Hu, Y., Deng, Y., Chan, F. T. S., \& Ishizaka, A. (2018). A DEMATELbased completion method for incomplete pairwise comparison matrix in AHP. Annals of Operations Research, 271(2), 1045-1066. https:// doi.org/10 